\title{
Ancient Urban Assemblages and Complex Spatial and Socio-Political Organization in Iron Age Archaeological Sites from Southern Africa
}

\author{
Plan Shenjere-Nyabezi and Gilbert Pwiti
}

The Iron Age of southern Africa is dated from around the 1st Century AD and archaeologically understood as the result of population movements from further north and generally associated with the advent of settled agro-pastoral communities in the region. Although areas of uncertainty and disagreement still remain in the scholarly community, it is generally accepted that until sometime towards the end of the ist millennium $\mathrm{AD}$, these communities were basically non-stratified village-based societies that lacked significant differentiation in political, social and economic terms. Economically, they were subsistence agro-pastoral people who relied on the cultivation of crops such as millet and sorghum and the rearing of sheep/goat and cattle. The archaeological evidence indicates that they lived in villages of varying sizes from as small as 1 hectare to as large as 10 hectares which were made up of simple houses of the cone-on-cylinder type (Pwiti, 1996) (Figure 4.1).

There is very little evidence of differentiation of people within and between villages and somewhat limited evidence of occupational specialisation, except perhaps in the context of the manufacture of pottery and the processing of iron ore into utilitarian products such as arrow or spear heads, axes and hoes which were used for hunting and for agricultural engagements, respectively. Essentially therefore, in terms of socio-political and economic organisation, the early farming communities represented what anthropologists have traditionally classified as "tribal" societies or what in other circles, are now also referred to as non-stratified peasant village societies (Maggs, 1984; Pwiti, 1996a; Friedman and Rowlands, 1978).

Towards the end of the 1st millennium AD into the early part of the and millennium AD, however, the farming communities of southern Africa underwent a number of important changes which among other things saw the development of socio-political and economic stratification as well as changes in settlement organisation and settlement types. This is the background against 


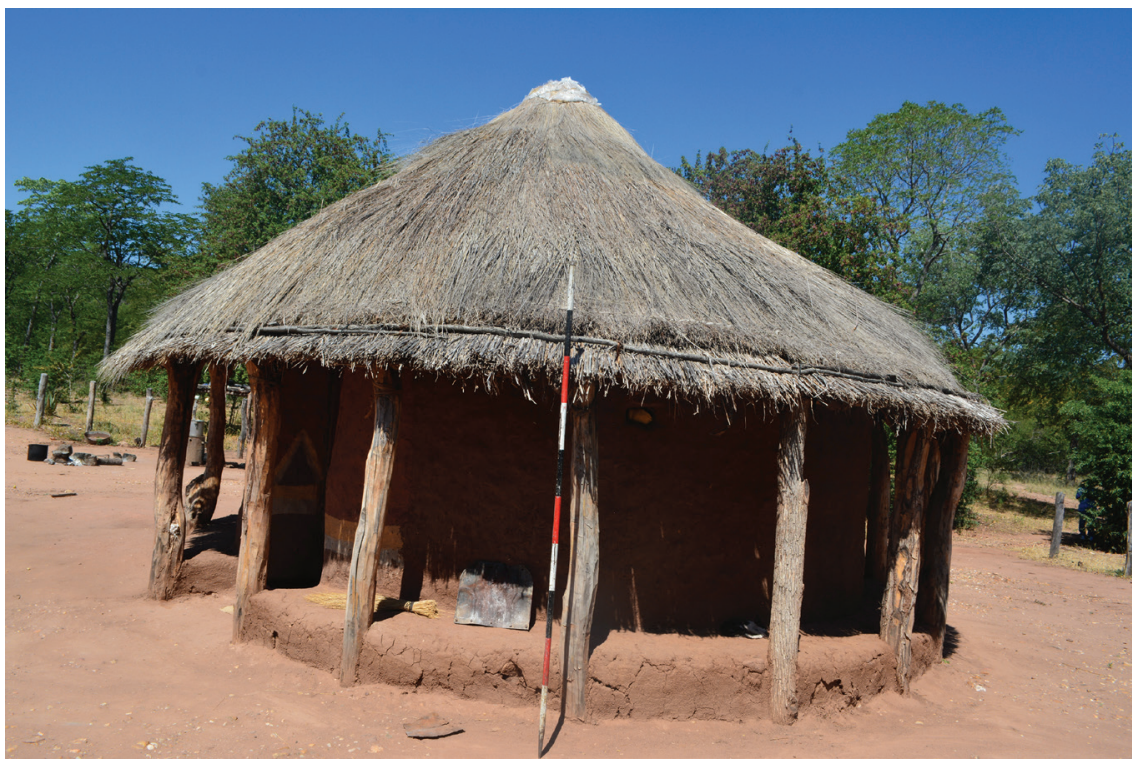

FIGURE 4.1 Cone-on-cylinder type houses

which the archaeology of farming communities of southern Africa has traditionally been divided into two main periods, an Early Iron Age (EIA) and a Later Iron Age (LIA) with the change over placed at around $1000 \mathrm{AD}$. In the past, the two periods were seen as bracketing separate cultural phenomenon, with the LIA communities being seen as new migrants into the region who replaced the EIA (Phillipson, 1977). However, new field research accompanied by the application of, and development of new theoretical frameworks over the years has persuaded the view that while the changes in the region were notable and seemingly dramatic, they were not the result of new population arrivals but rather the result of gradual changes among the EIA, thus representing a clear case of continuity and change (Hall, 1987; Maggs, 1992; Pwiti, 1996). Apart from the changes in socio-political organization briefly alluded to above, other notable changes that are observable during the late 1st millennium AD into the 2nd millennium AD included changes in ceramic style, which itself was a major premise for the population replacement thinking and a basis for the division of the Iron Age into two cultural periods. Ceramics of the EIA communities reflected fairly widespread homogeneity in space and time and was characterized by the manufacture of pots with thickened rims and lavish comb stamping decoration on the rim, neck and neck-shoulder area. In contrast, ceramics of the later period reflected considerable heterogeneity and somewhat poorer finish and less elaborate style. As noted above, settlement types and patterns also changed from the widespread location of settlement sites along river and stream valleys during the E IA to the location of settlements on 
higher ground, including hilltops (Maggs, 1984). It is archaeologically observable that the settlement structures also became more substantial, compared to the flimsier structures of the EIA and with time, one of the major changes was the appearance of stone buildings as part of the settlement systems. Over and above these many changes, there is also evidence of population increase, as more settlement sites of the later period have been recorded across the region.

Perhaps the most outstanding changes were seen in economic organization, a factor which becomes important in relation to the development of complex societies and the origins and growth of the urban assemblages that are the concern and subject of this paper. Here, the evidence indicates that towards the end of the ist millennium $\mathrm{AD}$, a notable change is seen in the domestic animal economies where cattle herds increased substantially compared to small stock (Table 4.1).

TABLE 4.1 Increased cattle herds against decreased small stock at nine Iron Age sites using both NISP and MNI

\begin{tabular}{|c|c|c|c|c|c|c|c|}
\hline Sample & $\begin{array}{l}\text { Cattle } \\
\text { NISP }\end{array}$ & $\begin{array}{l}\text { Sheep/ } \\
\text { goat } \\
\text { NISP }\end{array}$ & $\begin{array}{l}\text { Cattle } \\
\text { index }\end{array}$ & $\begin{array}{l}\text { Cattle } \\
\text { MN I }\end{array}$ & $\begin{array}{l}\text { Sheep/ } \\
\text { goat } \\
\text { MNI }\end{array}$ & $\begin{array}{l}\text { Cattle } \\
\text { index }\end{array}$ & References \\
\hline Nanda (AD 6th-7th) & 112 & 553 & 0.17 & 14 & 55 & 0.20 & Plug 1993 \\
\hline $\begin{array}{l}\text { Bosutwe Taukome } \\
\text { (AD 700-80o) }\end{array}$ & 101 & 76 & 0.57 & 10 & 13 & 0.43 & Plug 1996 \\
\hline $\begin{array}{l}\text { Bosutswe Toutswe } \\
\text { (AD 800-1200) }\end{array}$ & 1125 & 698 & 0.62 & $5^{2}$ & 46 & 0.53 & Plug 1996 \\
\hline $\begin{array}{l}\text { Bosutswe } \\
\text { Mapungubwe } \\
(\text { AD 1200-1300) }\end{array}$ & 1197 & 554 & 0.68 & 47 & 36 & 0.57 & Plug 1996 \\
\hline $\begin{array}{l}\text { Bosutswe Zimbabwe } \\
\text { (AD 1450) }\end{array}$ & 227 & 106 & 0.68 & 9 & 12 & 0.43 & Plug 1996 \\
\hline $\begin{array}{l}\text { Boitsemagano } \\
\text { (AD 17th century) }\end{array}$ & $5^{69}$ & 188 & 0.75 & 34 & 20 & 0.62 & $\begin{array}{l}\text { Plug \& } \\
\text { Badenhorst } 2006\end{array}$ \\
\hline $\begin{array}{l}\text { Mabjanamatshwana } \\
\text { (AD 17th century) }\end{array}$ & 449 & 118 & 0.79 & 79 & 41 & 0.66 & $\begin{array}{l}\text { Plug \& } \\
\text { Badenhorst } 2006\end{array}$ \\
\hline $\begin{array}{l}\text { Molokwane } \\
\text { (AD 17th century) }\end{array}$ & 1702 & 426 & 0.8 & 90 & 49 & 0.65 & $\begin{array}{l}\text { Plug \& } \\
\text { Badenhorst } 2006\end{array}$ \\
\hline $\begin{array}{l}\text { uMgungundlovu } \\
\text { (AD 1829-1839) }\end{array}$ & 2576 & 8 & 1 & 124 & 6 & 0.95 & $\begin{array}{l}\text { Plug \& Roodt } \\
1990\end{array}$ \\
\hline
\end{tabular}


In the broader framework and beyond purely economic considerations, this development laid the foundations of the political, social and ideological importance of cattle that became one of the mainstays of the socio-political fabric of southern Bantu societies during the Iron Age which has continued into modern times (Shenjere-Nyabezi, 2016). Another major economic change was the development of external trade relations between the southern African interior and the outside world via the Indian Ocean Coast and mainly with the Oriental world (Pwiti, 2005). As expanded on below, this economic development had major repercussions on socio-political developments in the region that relate closely to the concerns of this paper.

\section{2 Socio-Political and Economic Transformations}

The reasons for the transformations that took place in the region around 1000 AD have been a matter of scholarly debate for many decades. As noted above, the transformations were originally explained as resulting from the arrival of new populations into the region, populations who were equipped with higher forms of socio-political and economic organization who then replaced the earlier farming communities. This explanation was rooted within migrationist theoretical frameworks that were in vogue at the time. Since then, with the growing global wave against migrationist thinking and the adoption of popular theoretical operational frameworks such as systems thinking in archaeology archaeologists began to think in terms of internally driven systems growth rather than externally stimulated socio-economic and political development (Renfrew, 1984). Re-examinations of some of the ceramic breaks also began to argue against migrations while some archaeologists argued for ideological change although from different directions and on different platforms (Pwiti, 1996; Pwiti, 2004; Garlake, 1982). For example, Garlake argued that the ceramic and other changes were explainable in terms of a change from matrilineal social systems in the EIA to patrilineal societies in the latter period (Garlake, 1982). For Garlake, this explained the change from the better quality and more elaborately decorated ceramics of the EIA to the less stylistic ceramics of the LIA. He argued that the ceramics of the EIA were manufactured by specialist male potters while LIA pots were made by women for household consumption, hence the poorer finish. Apart from the sexist connotations of Garlake's argument, this does not seem to have provided an explanation for all the other observable changes. Pwiti on the other hand argued that the changes were the result of ideological change from an ideology of equality and the ethic of sharing during the EIA to an ideology of accumulation which in due course saw the 
emergence of social, economic and political inequalities that were to characterise the LIA communities in prehistory through to historical times, as complex societies developed, grew and declined in the region (Pwiti, 1996c, 2004).

While the debate on explaining the changes continues, what is important to note here in the context of this paper is that during the and millennium AD, the farming communities went through major changes which were accompanied by important political developments in the form of complex societies, initially at the chiefdom level and in the course of time, the development of state societies particularly from the 11th Century AD (Pwiti, 1996c). Away from explaining the various changes that took place at the turn of the millennium, archaeologists have also expended considerable intellectual energy in trying to explain the development of complex societies in the region. Traditionally, the most popular explanation was external in outlook where the introduction of external trade towards the end of the 1st millennium AD is argued to have introduced a new form of wealth that was monopolised by a few individuals who grew wealthy and powerful and used their newly found wealth as a base for building political power (Huffman, 1984b; Pikirayi, 2013; Kusimba and Kusimba, 2017). Ultimately, this was to see the emergence of the region's earliest complex systems which eventually grew into major systems such as the Zimbabwe state based at Great Zimbabwe. Popularly known as the "trade hypothesis", this explanation was grounded in global theoretical frameworks of the day which were to be subjected to considerable criticism from the late 1970 with the development of inward rather than outward looking explanations that came in the wake of the growth of post-processual archaeology.

Others have also advanced religion as a causative factor where it has been argued that complexity developed as a result of some individuals acquiring religious influence where they used the power and mystery of their relationship with the supernatural to build social, economic and political power (Garlake, 1973). This is thought to have been particularly effective in the context of important branches of production such as agriculture where the power of such individuals to intervene with the supernatural to give or withhold rainfall for example would have made for social and political allegiances among ordinary people, with such allegiances having economic or material as well as political benefits. In as far as religion has always been part of statecraft, and from what is known about the relationship between religion and politics among historical southern African societies, it is undeniable that religion would have been important in the life of these complex systems. What is at issue however, is how religion would have originated the systems (Wenke, 1989; Pwiti, 1996c; Garbett, 1966; Bourdillon, 1987). Yet others have argued for and appealed to the warfare/conflict theory (Carneiro, 1981). In the southern African context, such 
thinking has also been advanced as part of the explanation of rising of Great Zimbabwe and other systems (Kusimba and Keeley, 2015). Here again, we do have historical evidence that warfare did take place in southern Africa. Portuguese records and oral traditions have shown, for example, that during the 17th Century, there was an armed conflict between the Mutapa state of northern Zimbabwe and the Changamire state based in the south west (Pikirayi, 2013). By extrapolation, we can expect that systems such as the Mapela, Mapungubwe and Zimbabwe states would have raised armies for defensive or offensive purposes. What remains problematic is accepting warfare as a causative factor, apart from the fact that warfare can be notoriously difficult to identify in the archaeological record, especially in the southern African context.

As an alternative to the external trade, warfare and religion hypotheses in the context of the development of complexity and more specifically Great Zimbabwe, Garlake argued that socio-political growth was best explainable in terms of the growth in the indigenous branches of production especially cattle herding, and others such as agricultural production and mining (Garlake, 1978; 1982). To this end, Garlake went so far as to dismiss the economic proceeds from external trade as peripheral to the growth of complex socio-political formations in the southern African past (Garlake, 1982). This position found support amongst historians such as Mudenge for the Rozvi state, a major but later complex state system in Zimbabwe as well as the Mutapa state (Mudenge, 1974; 1988). Around the same time and in later years, archaeologists such as Sinclair and Pwiti were to argue for a combination of factors (Sinclair, 1987; Pwiti, 1996). Using a systems thinking approach (while acknowledging some of its weaknesses), for example, (Pwiti, 1996) argues that external trade impacted on systems that were already in a state of growth in southern Africa and thus only accelerated a process that was already under way, rather than originating it (Pwiti, 2005; Chirikure et al., 2013; Cobbing, 1976). In this framework, it is argued that at the heart of the growth in the indigenous branches of production was cattle herding. As observed above, the archaeological evidence does show that cattle herds did increase among societies in different parts of the region. In time, cattle became an important source of social and political power. As evident from Portuguese documents on the Mutapa state as well as the historical complex systems such as the Zulu and Ndebele states and indirectly from the archaeological record, cattle were used as an avenue to political power and a base for holding on to such power (Cobbing, 1976; Kuper, 1982). For the formative stages, the more cattle an individual possessed, the more such individuals became powerful and influential economically, socially and politically (Garlake, 1978; Sinclair, 1987; Pwiti, 1996c; Shenjere-Nyabezi, 2016, 2018). It is then arguable that these are the local circumstances under which complex 
socio-political systems originated and developed. It is also then arguable that external trade brought in an additional form of wealth to systems that had grown wealthy as a result of local factors. In the final analysis however, we take the integrationist view that the development of complexity was the result of a network of economic, social and political actions. This is in the sense that the different economic activities relating to the complex systems that developed in southern Africa took place in social and political contexts at different levels from the household all the way up to the apex of the power structures. In these contexts and processes, people, cattle, exotic and local goods as well as services moved up and down in the networks to create, promote and cement relationships. Stated differently, centers of power relied on the local and wider regional networks and vice versa, thus bringing in the concept of Actor Network Theory as applied in Chirikure and more recently very ably articulated by Scholfield in examination and discussion of socio-political developments relating to the Zimbabwe Culture in the Shashi-Limpopo basin between the 1oth and the 14th Centuries AD (Scholfield, 2019; Chirikure et al., 2014). the Zimbabwe Culture

It has long been recognised that politically and economically powerful persons often sponsored monumental architecture as an expression of their power. COWGILL, 2004

The development of urbanism and complex socio-political formations in southern Africa is archaeologically best known from and associated with what has been defined and termed the Zimbabwe Culture. Archaeologically, the Zimbabwe Culture of southern Africa was the most successful of the several Later Iron Age cultures that developed during the 2nd millennium AD (Figure 4.2).

It is dated to the period between the 11th and the 19th Centuries AD and apart from its distinctive graphite burnished pottery, it has largely been defined by its monumental stone walls that come in a variety of styles and constitute its most striking and immediately visible attribute. Traditionally, this archaeological culture was conventionally divided into 3 phases, a Mapungubwe phase (AD1220-1290), a Zimbabwe phase (AD125O-145O) and finally the Khami phase (AD145O-165O). In the absence of clear chronological data, these phases were derived from the major sites of Mapungubwe, Great Zimbabwe and Khami whose rise and collapse were assumed to have been in tandem. However, 


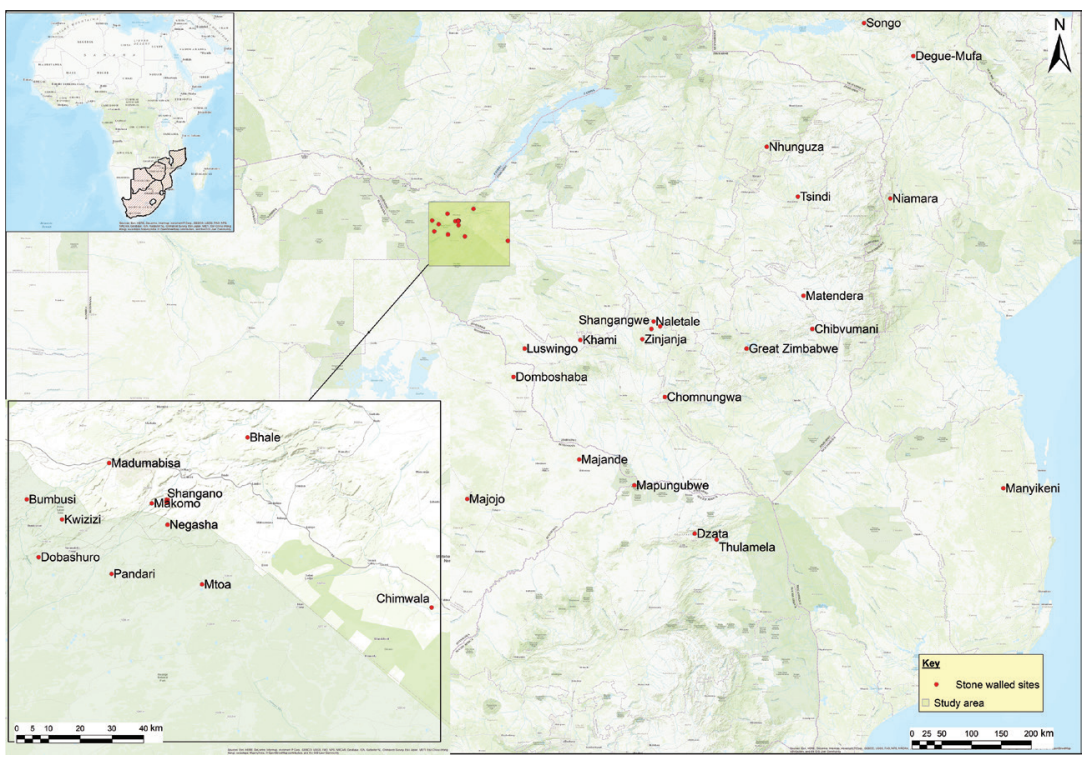

FIGURE 4.2 Map of Southern Africa showing Zimbabwe Culture sites

recent research has shown that some of these sites chronologically overlap thereby challenging the linear evolutionary framework (Chirikure et al., 2016; Shenjere-Nyabezi et al., 2020). The definition of the different phases has been based on variation in architectural style as well as other archaeological considerations such as changes in ceramic style. The stone wall stylistic classification was defined by Anthony Whitty, an architect, back in the 1950s (Whitty, 1961, 1959). The classifications were largely based on architectural considerations, including the refinement of walling. Building on earlier observations by Schofield and others at Great Zimbabwe, Whitty defined four architectural styles for the Zimbabwe Culture, namely, P (Poor), PQ (Poor/Quality) Q (Quality) and R (Rough) (Figure 4.3) (Whitty, 1961).

This classification was then translated into an evolutionary sequence where there was thought to be a refinement and progressive development in building and construction skills from the original poor walling in $\mathrm{P}$ style, a transition towards better construction skills represented by $\mathrm{PQ}$ style (a combination of $P$ and Q) and culminating in the perfection of walling with Q style, which the British antiquarian Bent described as "The best of what we call the Zimbabwe culture" (Bent, 1896). R walling was thought to represent degeneration in building and construction skills and associated with culture decline.

Influenced by their western home backgrounds and experience, many early European observers interpreted the Zimbabwe Culture stone walling as defensive and described the ancient city of Great Zimbabwe as a fortress (Bent, 1896; Hall, 1905). This was an unsurprising view, given that many monumental or 


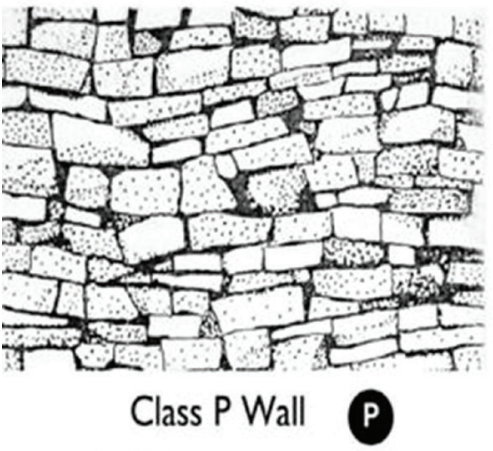

Poor coursing

Irregular blocks forming wavy courses

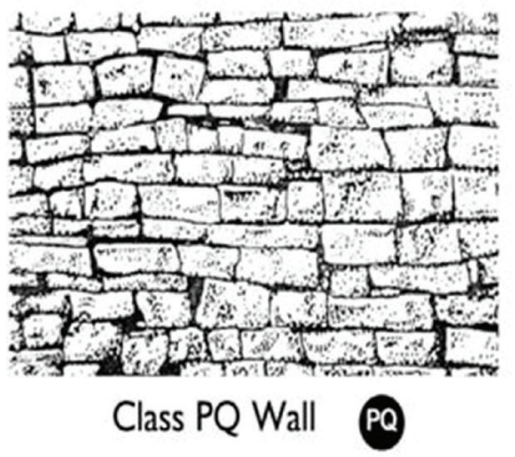

Intermediate between $P$ and $Q$
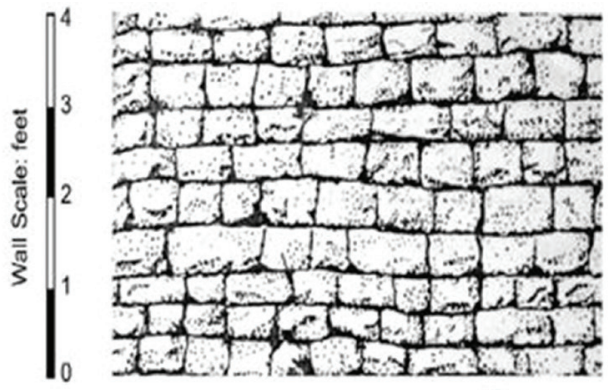

Class Q Wall Q

Quality walls using regular blocks Forms long regular courses
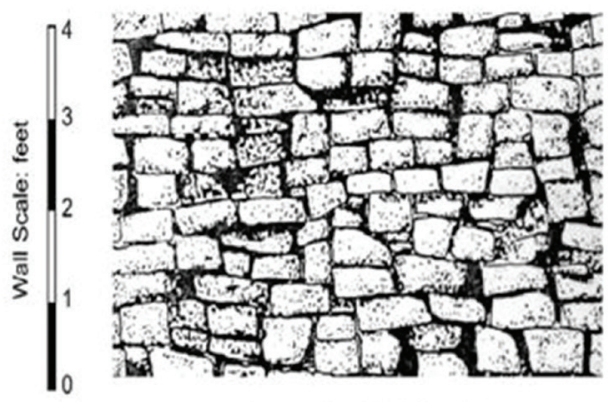

Class R Wall

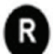

Haphazard, irregular blocks No coursing

FIGURE 4.3 P PQ Q R wall construction styles after WHITTY, 1961

stone-built constructions known in Europe and Asia were generally assigned a defensive fortification function without consideration of any other possibilities, an interpretation which is no longer wholly acceptable as recently discussed by Ashkenazi (Ashkenazi, 2020).

Others, who were awed by the grand and visually impressive parts of the settlement such as the Great Enclosure and the Conical Tower therein, preferred to interpret such parts of the site as the result of religious inspiration and therefore representing a temple (Hall and Neal, 1902). This was in the context of the exotic origin hypothesis for the Zimbabwe Culture and its architecture where the whole complex was attributed to Phoenicians and Arabs, among a host of other foreign candidates (Hall and Neal, 1902; Mahachi and Ndoro 1997). It is of some interest to note here that the exotic identity has not altogether died as reflected in recent publications such as Nyamutswa (Nyamutswa, 2017). Nyamutswa has argued that Great Zimbabwe was the product of 
the Remba people, a Shona speaking group who claim a Jewish origin. Drawing on his Remba identity and Jewish origin thereof, Nyamutswa has specifically argued that the Great Enclosure was constructed to function as a male circumcision centre (circumcision being a central part of being Jewish). He cites several lines of evidence, including what he sees as the dominance of phallic symbolic objects recovered from the Great Enclosure and used in circumcision ceremonies. Equally important, he has resurrected the 19th Century interpretation of the Conical Tower in the Great enclosure as a colossal phallic symbol. The interpretation is however fraught with chronological and many other archaeological problems. Chief of these is the fact that Nyamutswa only provides an interpretation of the Great Enclosure and virtually ignores all other parts of the ancient city of Great Zimbabwe. He further fails to offer any interpretation of the hundreds of other similar stone-built sites across southern Africa and offers no supporting evidence for his argument and interpretation that Great Zimbabwe was constructed much further back in antiquity (to correspond with a Jewish origin) than what the currently available scientific dating has shown.

The religious interpretation of Great Zimbabwe and similar sites has not been the preserve of foreigners however. Among many indigenous people of southern Africa, Great Zimbabwe and related sites are indeed held as sacred and for Great Zimbabwe itself there have always been very strong local claims and sentiments that it was constructed as a religious centre (Pwiti, 1996b). That the stone buildings may have had cosmogramic associations and significance cannot be in doubt. What is doubtful however, is the claim that such edifices were erected for, and to fulfill religious functions. This is because it is well known that Shona traditional religion or indeed any other indigenous religion in southern Africa did not and has never required such monumental buildings (Bourdillon, 1987).

Following the discard of the exotic origin hypothesis over the years, there is now general agreement that Zimbabwe culture stonewalling was constructed for prestige, standing as symbols in action and a highly visible outward expression of the wealth, power and prestige of the ruling classes (Pikirayi, 2001; 2013).

The relationship between geography and archaeology has a long history in as far as both disciplines trade in and deal with space and the cultural manifestations across it (Hodder and Orton, 1976). In this regard, archaeological 
concerns with spatial analysis going back many decades and conceptual issues and definitions of past human imprints of such phenomenon as urban centres or cities have taken their lead from geography (Fox, 1943). In this context, an urban centre, considered at the simplest level, is geographically understood as a built up area in which there resides a large population characterised by high population density, with such populations engaged in a variety of activities beyond basic subsistence. Such centres will normally be run by a bureaucracy and may entail the existence of craft specialists and land use is intensive. From an archaeological perspective, perhaps one of the best surveys on urbanism in recent years is that of Cowgill (Cowgill, 2004). In a wide ranging theoretical expose of the concept of urbanism as archaeologically understood, accompanied by a global survey of major sites, Cogwill provides a number of useful platforms against which the stone walled buildings of the Zimbabwe Culture can be examined and understood as urban formations (Cowgill, 2004). One such is the observation that urban centres or cities are typically political, economic and religious centres for a surrounding territory and loci for wider ranges of specialised production and sources than are found elsewhere in the region (Cowgill, 2004). As already noted above, and elaborated below, there is now general agreement that sites such as Great Zimbabwe, Khami and the Shangano cluster were capitals of different Zimbabwe Culture political systems that flourished across southern Africa between the 11th and the 19th centuries AD. At Great Zimbabwe and elsewhere, there is abundant obvious evidence that commercial transactions involving exotic and local goods were the order of the day while specialised production of goods such as pottery and iron implements is clearly evident (Chirikure, Nyamushosho et al., 2018; Mtetwa, 2017). To this end therefore, there can be little doubt that in terms of the functional attributes of urban centres, whether political or economic, major sites of the Zimbabwe Culture were clearly urban in character and form. To this may be added the demographic aspect where excavations at different sites of the culture across the region have revealed that the monumental stone walled enclosures screened houses of the ruling elites while unwalled areas accommodated houses of sizeable populations of commoner people. In other contexts such as Khami, elite houses were built on platforms that were also surrounded by commoner settlement (Robinson, 1959; Mukwende, 2018). While the population estimates for Great Zimbabwe and other large sites have been problematic and controversial, the density of houses outside enclosures indicates that there would have been several thousands of people living there at any one given time. Past estimates by archaeologists such as Garlake and Huffman for Great Zimbabwe (which are now seen as unrealistic) argued for populations running up to between 10 ooo and 18 ooo (Garlake, 1973). More recent 
estimates based on the use of new techniques and extrapolation of historical population estimates for the Zimbabwe plateau as well as archaeological data by Chirikure and his associates now argue for more conservative figures of around 8000 (Chirikure et al., 2017). Whatever the case may be, what remains clear is the fact that the larger of the Zimbabwe Culture sites were major population centres, thus conforming to Cowgill's qualification that "Populations of at least a few thousand seem necessary if not a sufficient requirement for a settlement or society to be urban" (Chirikure et al., 2017; Cowgill, 2004).

Other important geographical and archaeological definitions and criteria for urbanism have highlighted that urban centres are constituted of built up areas accompanied by or made up of monumental structures. In addition, the existence of public buildings has also been added as important, though not necessarily regarded as a major defining attribute. Global surveys of complex societies and related centres from the Americas, Europe and through Africa to Asia have indeed shown that there is a degree of correspondence and relationship between monumental constructions and the development and manifestations of urbanism. As far as this goes, the monumental stone buildings of the Zimbabwe Culture and their spatial extent and layout clearly stand as physical evidence of their being urban. Here, we may however note that the Zimbabwe culture exhibits two types of urban patterning, the concentrated and discrete pattern and the dispersed urban pattern. Centres such as Mapungubwe, Great Zimbabwe and Khami are good examples of the first type while the Zvongombe cluster in northern Zimbabwe and the Shangano cluster in north-western Zimbabwe represent examples of the latter (Sinclair et al., 1993; Shenjere-Nyabezi et al., 2020).

However, while we embrace the concept of monumentality and other attributes in defining and understanding urbanism, we acknowledge that elsewhere in Africa and possibly beyond, it has been archaeologically argued and demonstrated that the absence of visible monumental structures is not a demonstration of the absence of urban centres in the past (McIntosh, 1999). Indeed, as McIntosh and McIntosh (McIntosh and McIntosh, 1984; McIntosh, 1999) have shown, cities without citadels did exist and did flourish in parts of West Africa. Elsewhere, in East Africa, historically observed urban capital sites of the interlacustrine states of Buganda, Bunyoro, Nkore and Rwanda, for example, have left no immediately visible traces of the expansive royal capitals that were constructed from perishable organic materials (Connah, 2015). In the final analysis therefore, it seems clear to us that whether it is being considered in the southern African or the Medieval England or the Mesoamerica past, urbanism was a complex phenomenon and development where there is a clear need to take into account variability in terms of process, development, 
form and character. This is a contention that is well articulated in Jervis (2016) that "...not only do different forms of urbanism exist, but that if urbanism emerges at the intersections between assemblages...towns emerge through various forms of discourse", hence his and our adoption of the concept of "multiple urbanisms" (Jervis, 2016; Kapumha, 2019).

\section{5 Urbanism and the Zimbabwe Culture Architecture}

The Zimbabwe Culture architecture has been the subject of archaeological and architectural inquiry for some time since the original exploratory studies by Schofield and the more comprehensive studies carried out by the architect Antony Whitty. Essentially, the architecture that resulted in the monumental buildings belongs to the class of dry stone walling which consisted of the production of walls of varying heights, terraces and platforms. These were constructed without the use of mortar using dressed as well as undressed blocks of stones that were quarried from the surrounding landscapes. The raw materials used were greatly influenced, though not always, by the local geology (Kapumha, 2019). The majority of the raw material for the buildings was quarried from granite, which is perhaps the most widely available rock type across the Zimbabwe plateau where most of the buildings are found (Garlake, 1970). Elsewhere, such as in north-western Zimbabwe, sandstone was exploited while in the mid-Zambezi Valley in northern Zimbabwe, iron stone was used (Shenjere-Nyabezi et al., 2020; Pwiti, 1996). In Eastern Botswana, quartz was quarried for sites such as Majojo while in central Mozambique the major site of Manyikeni was constructed out of limestone (Sinclair et al., 1993). To this end, it is fairly clear that local geology and other factors played a role in the development of the Zimbabwe Culture architecture. This had certain implications for the types and styles of the assemblages that were produced as architectural artefacts.

In summary, the construction of Zimbabwe culture stone buildings started with the quarrying of the raw materials. This took the laborious processes of subjecting rock outcrops to extreme heat, which would crack the rock into slabs, followed by shaping the resultant slabs into building blocks. It is thought that the process of transforming the raw materials into usable building blocks made use of stone and iron tools. Considering the number of blocks required to construct an edifice of the magnitude of the Great Enclosure at Great Zimbabwe, this must have required substantial inputs in work hours. This was followed by transportation of the building blocks to the construction site, which itself would have been a major feat. Finally, would come the process 
of construction of the dry stone walls, platforms and the other associated architectural features. Experimental work at Great Zimbabwe, accompanied by observations during the wall conservation work involving restorations have shown that substantial numbers of people and many days would have been required to construct even the shortest and smallest of Zimbabwe Culture structures (Dube, 199o; Matenga, 1996).

\section{Power, Status and Architecture: Costly Signalling and the Zimbabwe Culture}

As noted above, the most outstanding attribute of the Zimbabwe Culture was the monumental stone buildings that came in a variety of forms and styles. While it has been generally acknowledged that the stone walls were constructed as an expression and symbol of the power of the ruling classes, this interpretation has not previously been subjected to in-depth analysis and has more or less been taken for granted. In this section, we use two recent theoretical approaches and frameworks of Costly Signalling and Assemblage theory to further explore these stone built urban architectural remains.

\section{$7 \quad$ Costly Signalling Theory}

As a theoretical construct, Costly Signalling Theory (CST) originated from evolutionary biology and its recent adaptation to archaeological thought and practice has been developed following a number of concepts and understandings (Conolly, 2017). This has involved examination of, thinking about and interpretation of different archaeological phenomenon, including art, faunal assemblages and monumental constructions (Conolly, 2017). Such archaeological phenomena are viewed as reflections of actions and activities of past societies that carried or involved heavy investment and therefore were very costly from different perspectives, dimensions and directions. This includes considerations of heavy and costly investment in material, social, political and emotional terms. In traditional anthropological theory, which has also been applied in archaeology and other social sciences, such investment, actions and activities were embraced under the Conspicuous Consumption Theory. In the same vein and along similar lines, such behaviours have also been examined under the "Wasteful Advertising" theory. While embracing much of the thinking and premises of Conspicuous Consumption Theory, and to a degree, Wasteful Advertising Theory, the development of CsT over the past 
two decades or so and more recently has sought to examine and interrogate the archaeological record beyond the immediately visible. This has included seeking to understand how and why individuals or groups of people engaged in costly signalling.

\section{$8 \quad$ Understandings of Costly Signalling}

The concept of costly signalling has been understood in several but related senses. In one sense, it is read as a form of signalling strength and power in which the costs of the signal are unaffordable for the less wealthy and less powerful to attempt. In another sense, it is seen as engaging in investment in the production of non-functional objects and highly visible monuments that have no immediate material reward or benefit. This extends to overinvestment in signalling one's or a group's power and prestige through non-utilitarian material culture such as objects and monuments which translates to costly behaviours that have long term but non-material benefits to the participating individuals (Conolly, 2017).

Beyond the immediately visible from an archaeological point of view, such signalling is deduced from reflections of costly acts and belief, commitment and investment in lavish gift giving. Along the same lines, this also includes engagement in acts of substantial generosity. Here, it is noted from cultural and social anthropological studies that such costly signalling is not the preserve of complex societies, but rather cuts across different forms and expressions of socio-political organisation. This includes what anthropologists have called non-ranked societies or systems that do not have institutionalised or hereditary leadership structures such as the Big Man societies, systems that scholars do not consider complex societies in the structural and conventional sense (Harris, 1977).

In the context of the Zimbabwe Culture monumental stone built centres under discussion, costly signalling is reflected in a number of ways, areas and contexts. At Great Zimbabwe and related sites across southern Africa, substantial labour and other inputs were invested in the production of the monumental architecture. The final products were in the form of the different stone structures that were non-functional and did not fulfil residential or other practical purposes. Rather, they were constructed to make a statement about social, political and economic power and by definition a statement about status. In this sense, southern Africa reflected developments comparable to many other parts of the globe such as South America and Asia in the sense of the production of monumental architecture as part of the development of complex socio-political systems sometimes referred to as civilisations. 


\section{Costly Signalling at Great Zimbabwe}

The larger part of the architectural remains at Great Zimbabwe is in the form of enclosures. The Great Enclosure, situated in the valley, is the most impressive structure at Great Zimbabwe. (Figure 4.4).

Its outer wall, measuring some 178 metres in length and standing at a height of 10 metres is the largest single prehistoric construction in sub-Saharan Africa (Ndoro, 2001). Estimates of the number of blocks required to erect this edifice have varied between half a million and a million blocks. The interior contains a number of smaller stone enclosures and several solid mud platforms. At the back of the Great Enclosure is perhaps one of the most intriguing structures in the ancient city, the Conical Tower (Figure 4.5).

This is now regarded as a symbol of power rather than a phallic symbol, as early observers and more recently Nyamutswa believed (Nyamutswa, 2017). Its shape is similar to that of the clay granaries used in recent historical times and which continue to be used today and thus some scholars have theorised that it may have symbolically represented the rulers' ability to collect and store food grain tribute from among their subjects and also to care for them in times of drought and food shortage (Garlake, 2003). One other impressive part of the Great Enclosure is the parallel passage where an earlier wall is enclosed by the outer wall forming a long narrow corridor (Figure 4.6).

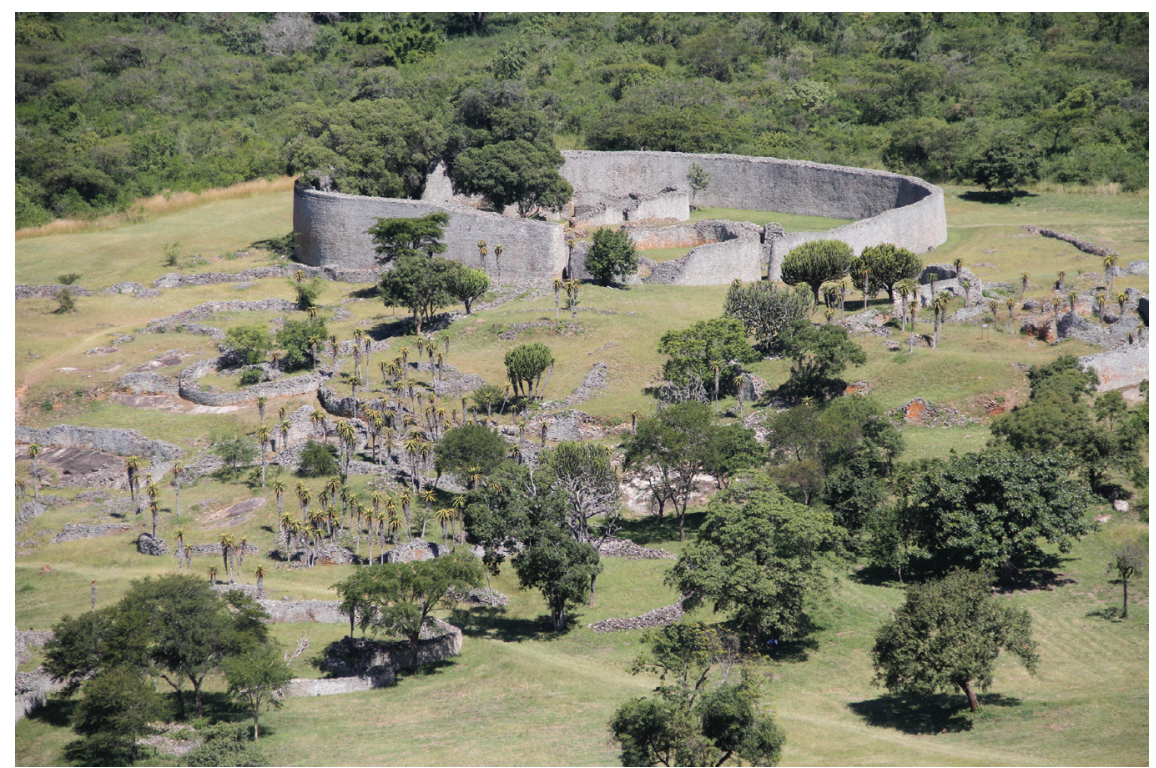

FIGURE 4.4 The Great Enclosure 


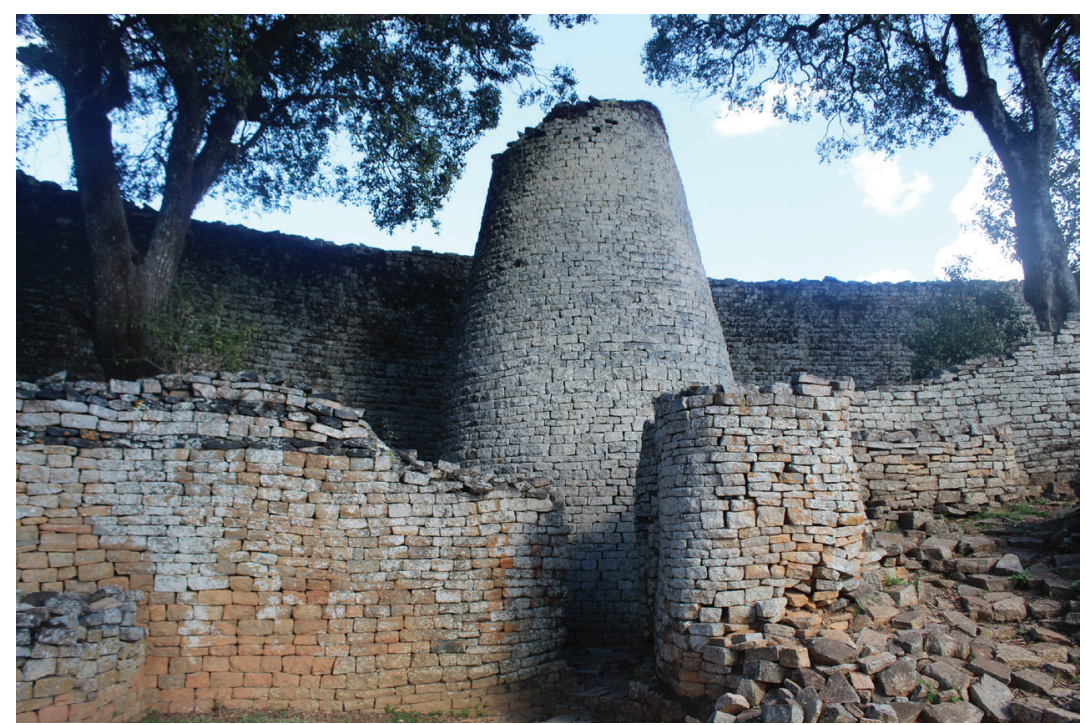

FIGURE 4.5 The Conical Tower

IMAGE BY MUNYARADZI ELTON SAGIYA

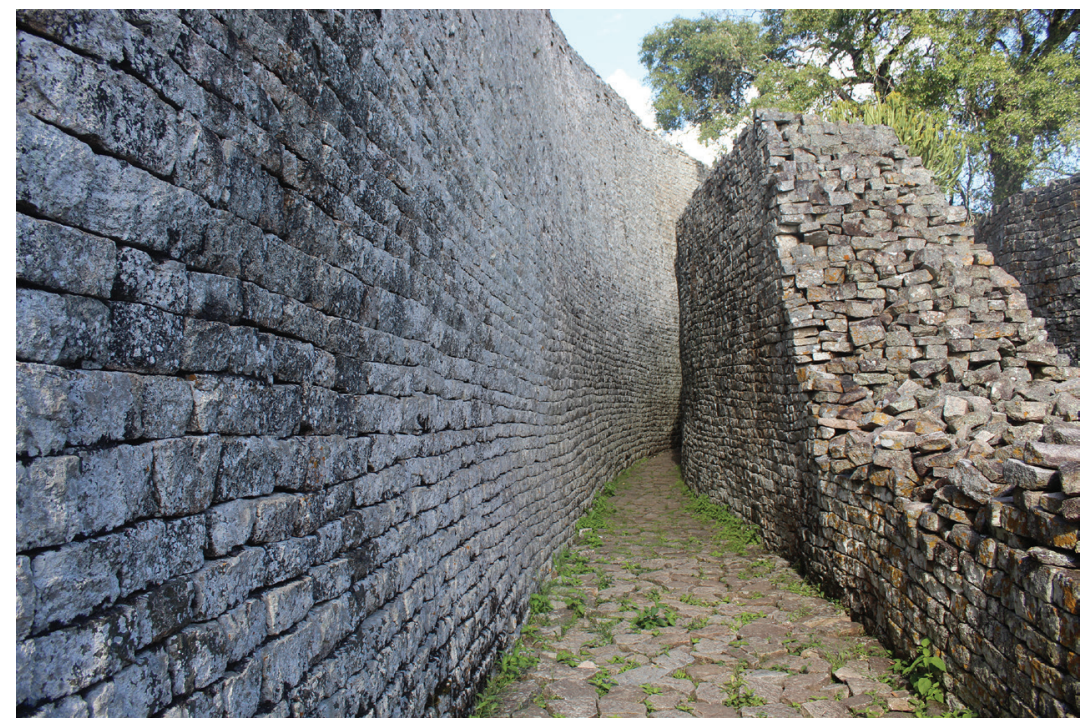

FIgure 4.6 The Parallel Passage

IMAGE BY MUNYARADZI ELTON SAGIYA

The outer wall demonstrates perhaps the highest level of masonry craftsmanship ever achieved at Great Zimbabwe. The top of the eastern outer-facing surface is decorated with a double chevron pattern and stone monoliths (Figure 4.7). 


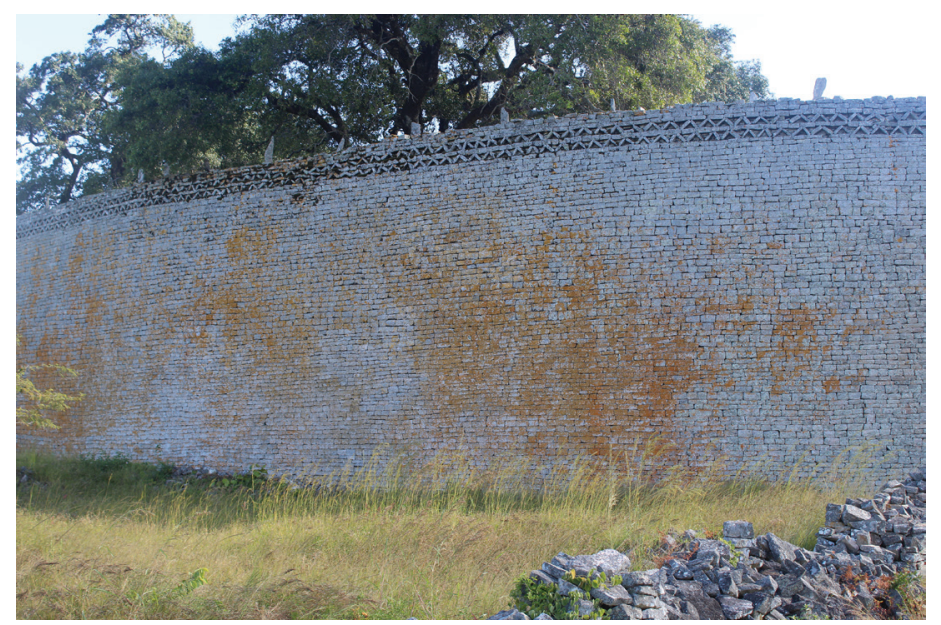

FIGURE 4.7 Double chevron and monoliths

IMAGE BY MUNYARADZI ELTON SAGIYA

\section{Khami and Other Zimbabwe Culture Sites}

While the stone enclosures at Great Zimbabwe were the dominant architectural features used for defining status and dividing space, away from there, at Khami the second largest Zimbabwe Culture site in southern Africa, as well as at Naletale and Danangombe, for example, the builders emphasised the construction of elaborate platforms on which thick solid walled mud houses were built. The platforms were connected by a system of passages, covered entrances and thick mud walls. Thus, while the elite people at Great Zimbabwe and related sites were screened within stone wall enclosures, the elite at Khami and the other sites mostly in central, south-western and north-western Zimbabwe exposed themselves on prominent artificial stone platforms (Figures 4.8A and $4.8 B)$.

One of the characteristic features of Zimbabwe culture stone buildings across space and time is the presence of decoration ranging from nominal to very lavish (Figs 4.9A and 4.9B).

Over the years, the decoration has been the subject of some debate. There has however been a general understanding that while it was artistic, it was certainly not art or style in the conventional Western sense, but rather fitted within the symbolic realm of things much in the same way the stone buildings 

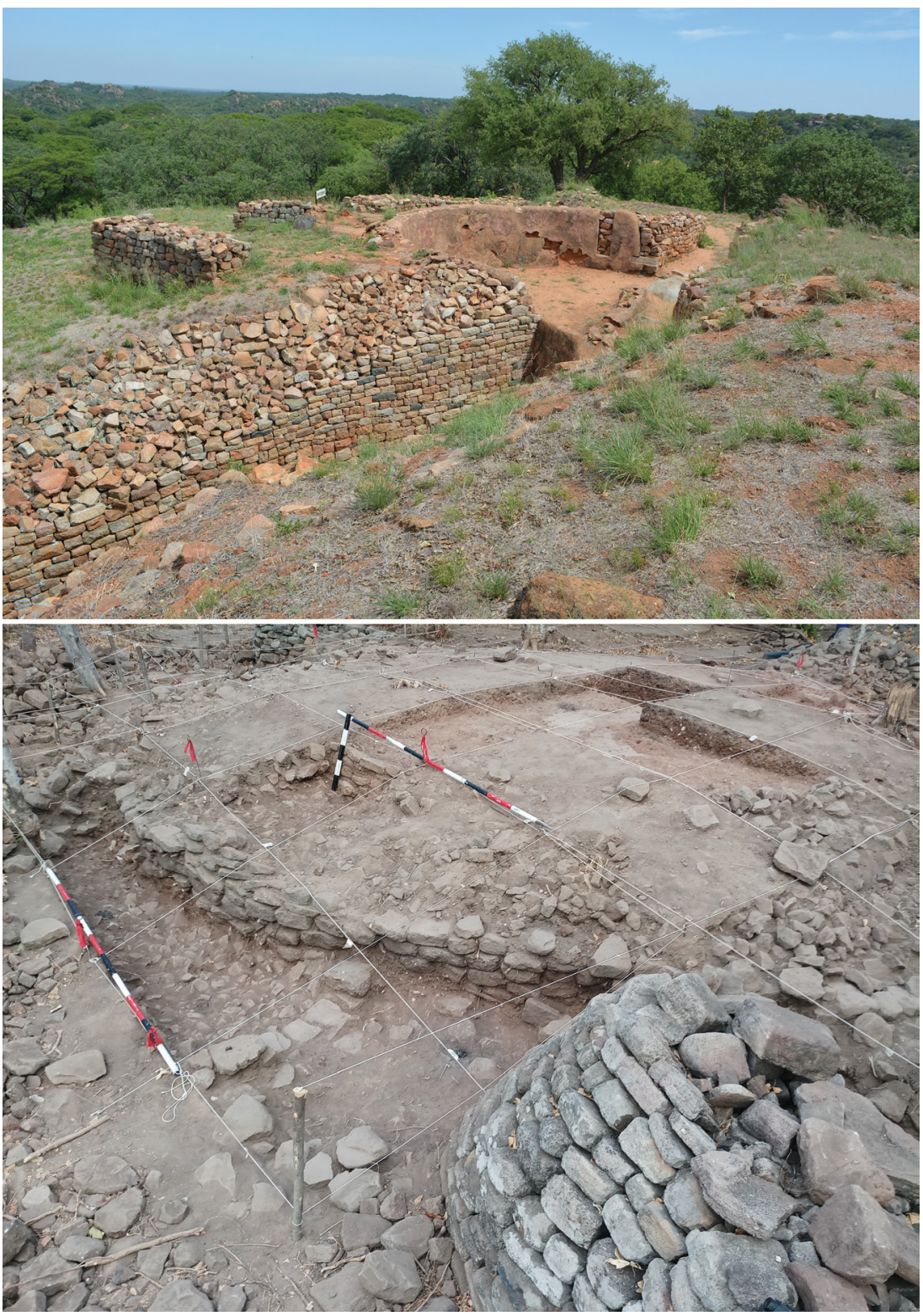

FIGURE 4.8 (A) Artificial House Platform at Khami, western Zimbabwe; (B) Artificial House Platform at Shangano site, north-western Zimbabwe

themselves were symbols in action. In this sense, there is general acknowledgement that the decorative motifs on Zimbabwe Culture sites were part of a symbolic code and a cultural grammar. It is against this background that Huffman $(1981,2007)$, has offered very comprehensive interpretations of the 

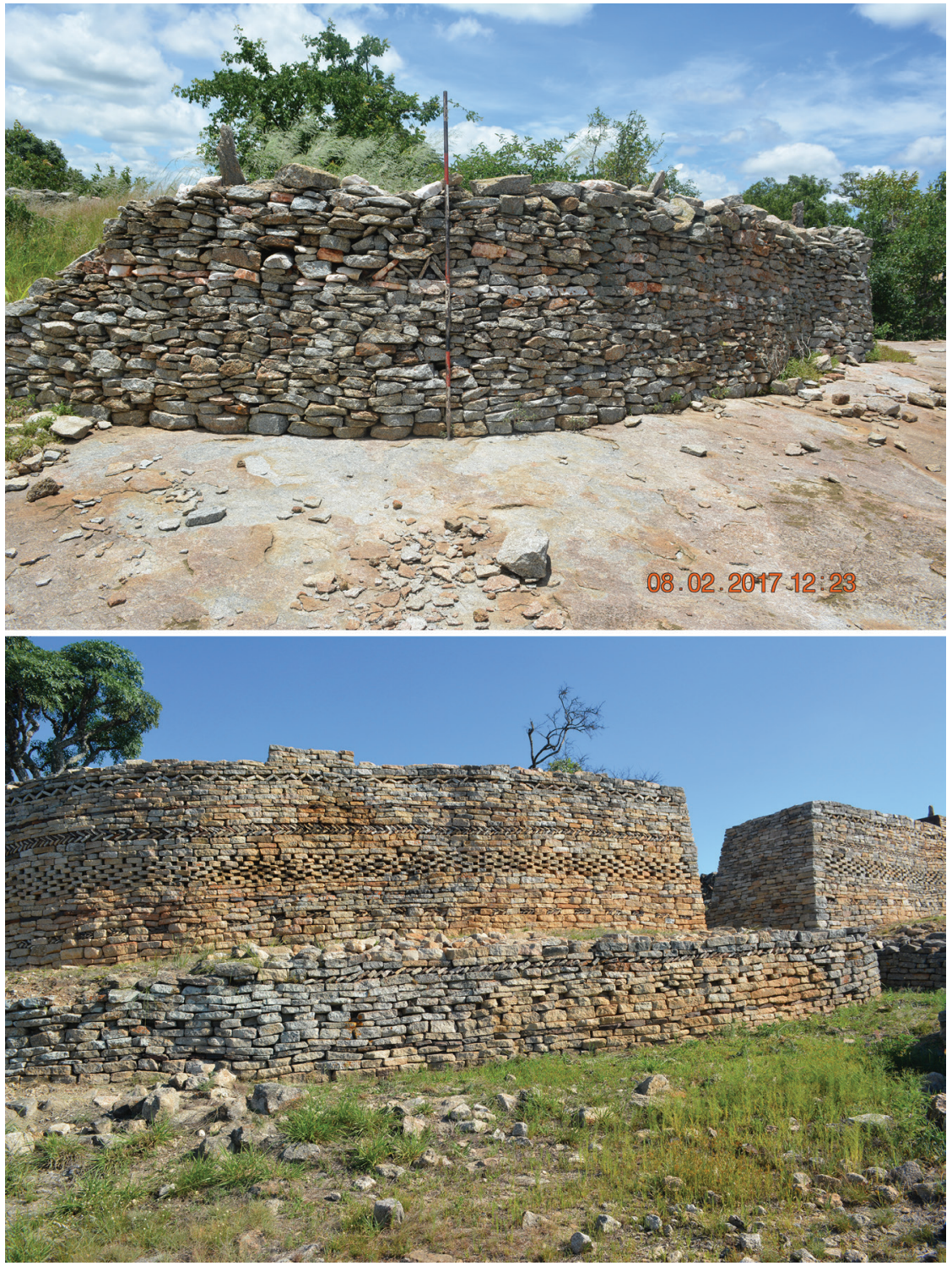

FIGURE 4.9 (A) Nominal decoration at Mtoa, north-western Zimbabwe; (B) Lavish decoration at Naletale, central Zimbabwe

meanings and significance of the many decorative motifs found on the walls and platform at Great Zimbabwe and elsewhere, mainly using Shona ethnography (Huffman, 1981; 2007). Although Huffman's work has been questioned and widely debated, its value has lain in the fact that it has provided for recognition and acknowledgement of the fact that the decorations were part of an urban 
cultural code of its times. Regardless of the debated meanings and symbolism of the decorations, what is important in the current consideration of costly investment is the observation that the decorations represented a substantial investment in terms of construction skills, labour and artistic creativity. To this extent therefore, they represented another level of costly signalling within the Zimbabwe Culture. What is also of interest in this regard is that at most of the sites where it occurs, the decoration is almost always found on places where it is highly visible, as if meant to be immediately readable (see Fig. 4.10A and 4.10B). Rare exceptions have however been noted at some sites where decoration is in the interior and therefore not immediately visible as at the sites of Nsalansala and Shangagwe in central Zimbabwe (Figure 4.10A and 4.10B).
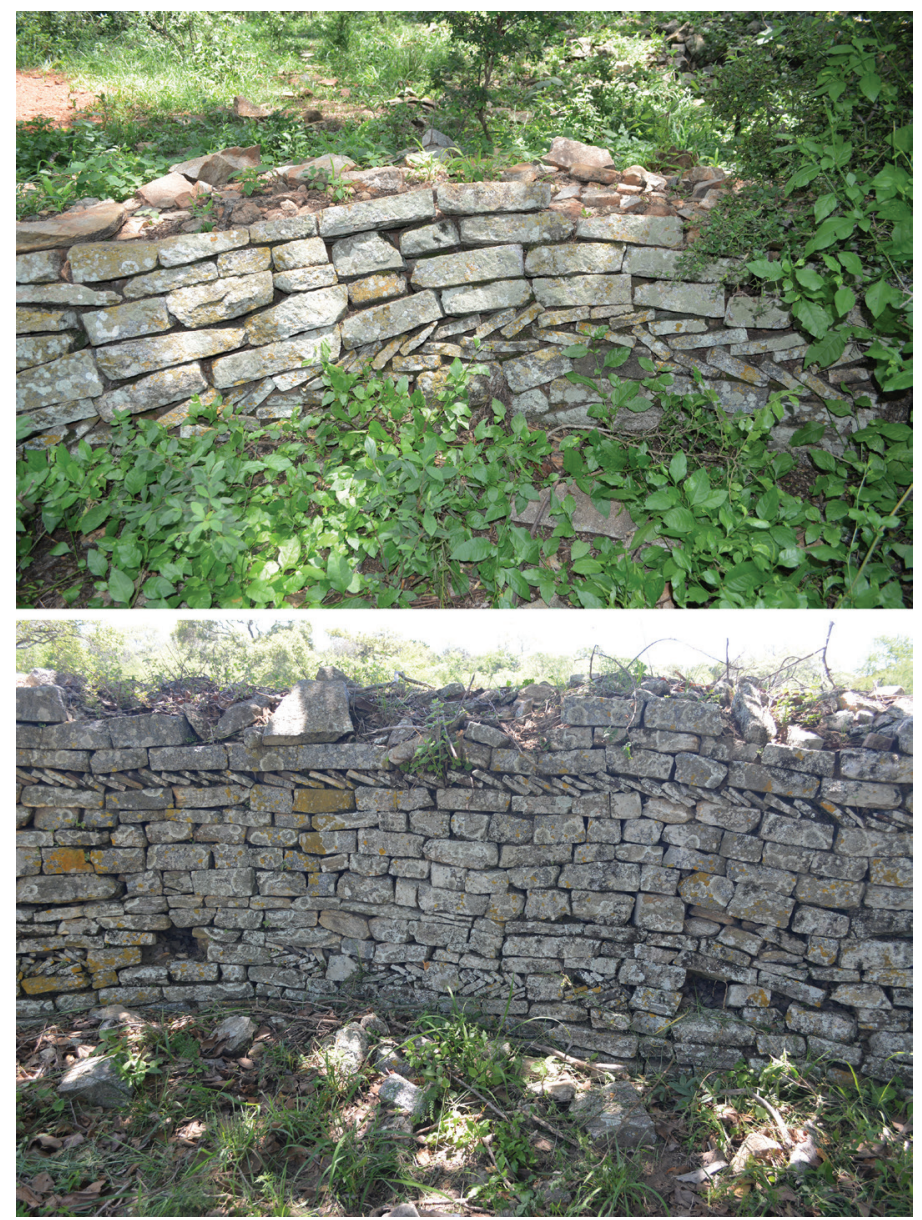

FIGURE 4.10 (A) Interior and less visible decoration at Nsalansala, central Zimbabwe; (B) Interior and less visible decoration at Shangagwe, central Zimbabwe 
Excavations at various Zimbabwe culture sites have shown that there was some differentiation in the production of residential structures between stone walls and on platforms and outside stone walls. Houses within stone walls and on platforms were all invariably constructed with thick solid dhaka (adobe) walls (Figure 4.11) and on substantial stone foundations with compact thick plastered floors.

These contrasted with the flimsier houses outside stone walls which were the pole and dhaka cone-on-cylinder type observed in historical times among Shona people. In as far the solid houses required considerable investment and input in their construction, they must have represented a structurally and visually more impressive product well beyond the normal requirements for accommodation purposes. It is against this background that it becomes observable that the elite domestic architecture of the Zimbabwe Culture urban centers constituted yet another level of costly signalling in relation to the costs invested.

In the final analysis, what emerges is that the various aspects of the material expressions of the Zimbabwe Culture represented a classic case of costly signalling where substantial labour and other inputs were invested in non-functional monumental production to make a statement about political power and status (Conolly, 2017; O'Driscoll, 2017; Wright, 2017).

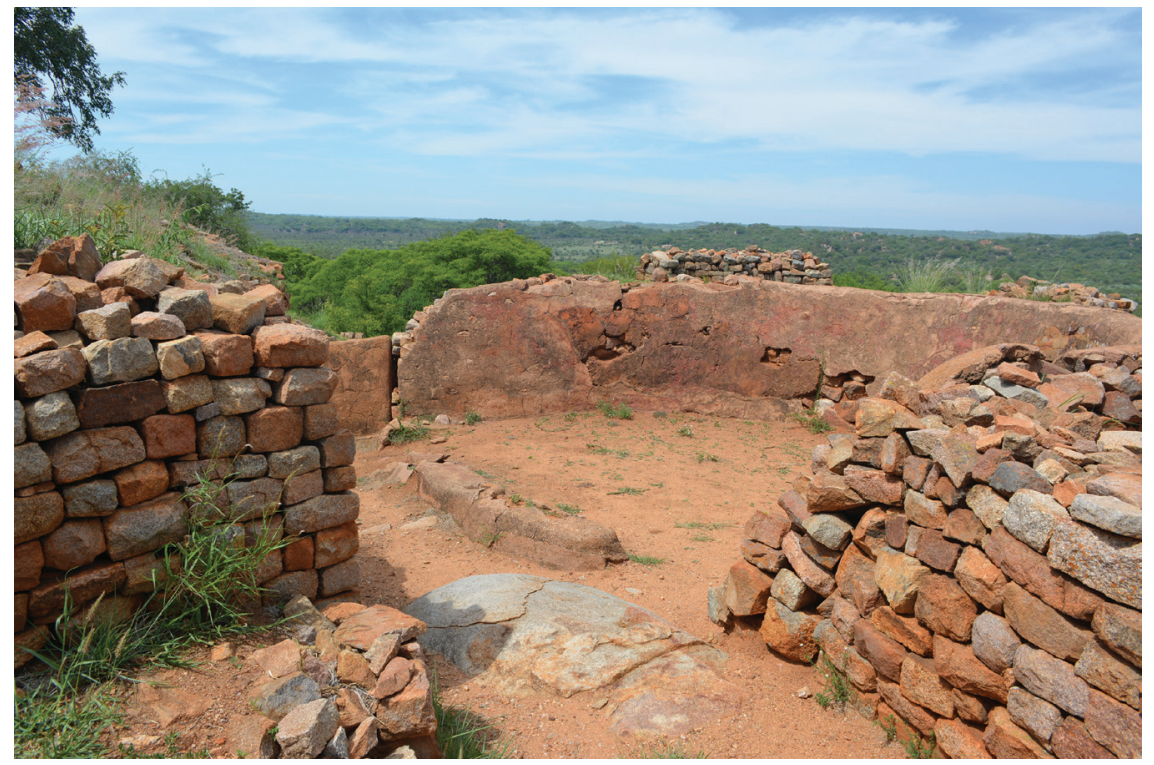

FIGURE 4.11 Solid dhaka (adobe) walls at Khami site, western Zimbabwe 


\section{Participation in Costly Signalling and the Zimbabwe Culture}

Throughout history, people have been duped again and again into believing that enormous inequalities in the distribution of wealth are necessary for their own welfare. HARRIS, 1977

From our presentation of the various forms of costly signalling above, one of the obvious observations would be that the stone edifices were not constructed by members of the elite, seeing as a major investment in labour and other arduous work was called for. Powerful elites would not normally engage in such exacting undertakings. There is therefore a commonly held and largely accepted (and acceptable) assumption that the buildings were the result of the sweat and blood of commoner people that was voluntarily offered to enable those in power to make statements about themselves. This assumption is particularly accepted in the absence of any direct evidence of the use of slave labour or compelling evidence of the use of some such other coercive measures. The question that presents itself which remains to be addressed is why people would have voluntarily participated in costly signalling of power and prestige which they themselves were not directly a part of or direct beneficiaries. Answers to such questions have been asked of many such highly demanding undertakings across the globe in prehistory and even in contemporary times. Today for example, people engage in costly and risky behaviors on behalf of political leaders or political parties where in the end, they do not really derive any direct personal benefit. In attempting to answer these questions, we appeal to theoretical constructs linked to the ideology of control, including the role of religion in making populations engage in acts and processes of costly signalling for no clear immediate benefit but rather a belief that participation in public works for the elite or the politically and economically powerful is good for them, as summarized by Harris' contention above. We here argue that the participation in costly signalling to produce the Zimbabwe Culture monumental architectural assemblages was situated within an ideology that made people to believe that such undertakings were good for them, rooted in a belief that what is good for the leader(s) is good for the common good. Costly signalling then becomes an instrument of ideological control where inequalities and outright exploitation are masked. This does not however, discount the ever present possibility that on the part of the commoners, there may have been a sense of pride and satisfaction to be gained or derived from participating or having participated in the production of something grand and lasting, and acting as a lasting reminder of a sense of belonging to and sharing in the greatness of a socio-economic and political system which they belonged 
to and identified with. In the end, the production of the monumental structures would have been part of the construction and production of identity and belonging as a long-term gain but not in the immediate material sense. Ultimately, this becomes hinged on the two theoretical concepts of belonging and identity (Cooper and Brubaker, 2005; Mujere, 2019; Hodder et al., 1982). In this case, this is in a context where material cultures such as architecture are deployed by sections of a given socio-political formation to reinforce and reflect a strong sense of being and belonging. This is regardless of the fact that some such sections of the society are the active and direct producers of the material manifestations of belonging while a small section is consumers and the larger beneficiaries.

14

\section{The Spatial and Socio-Political Organization of the Zimbabwe Culture Centres}

Intra-site spatial analysis in archaeology beyond functionalist approaches towards the quest to understand the significance and meanings of the organization of space came into vogue in the discipline during the early years of the post-processual archaeology era from the late 1970s into the early 1980 (Hodder et al., 1982; Hodder and Hutson, 2003). Much of the theoretical frameworks and methodological approaches took their lead in cultural anthropology based on work by Edmund Leach, among others. From this perspective in the context of this paper was the development of structuralist and cognitive models and thinking in anthropology. In southern African archaeology, the lead in the examination and analysis of the significance and meanings of spatial organization was taken up by Huffman in the seminal paper entitled Snakes and Crocodiles: Expressive space at Great Zimbabwe (Huffman, 1981). Much of Huffman's thinking and applications of structuralism were themselves heavily influenced, if not guided by South African anthropologist Adam Kuper's work on aspects of Zulu marriage as well as cosmology and its relationship to spatial organization (Kuper, 1980; 1982). In some of the applications that took their inspiration from Kuper's work, Huffman developed the archaeological settlement model for southern African EIA communities that was labelled the Central Cattle Pattern (CCP). Based on excavation work at sites such as Broederstroom in South Africa, it was argued that settlement sites of archaeological Bantu communities followed a fixed or standard spatial layout and pattern that was informed by the ideological and economic importance of cattle in the male world as well as by the higher status of men in society in relation to women (Figure 4.12) (Huffman, 2001; 1986; 1993). 


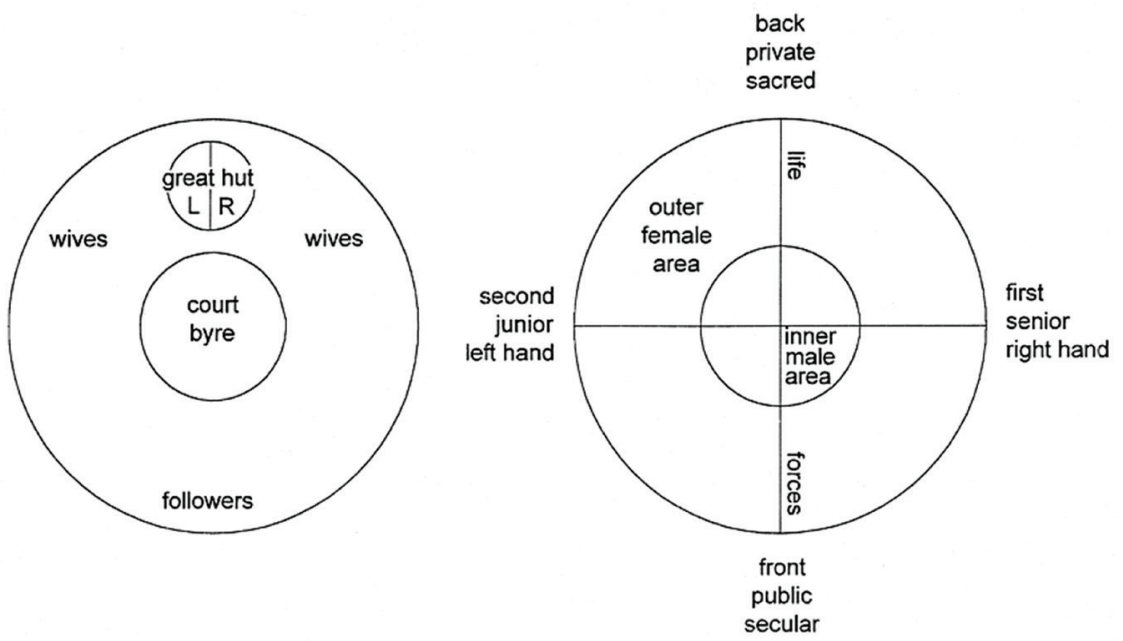

FIGURE 4.12 Structural arrangement of the Central Cattle Pattern AFTER HUFFMAN, 2001

The model has however been widely questioned on archaeological and other grounds (Hall, 1984; Lane, 1994; Shenjere-Nyabezi, 2016). It was also from and within the same intellectual background that Huffman also developed what he termed the Zimbabwe Culture Pattern which he argued was the product of transformations that took place among the farming communities of southern Africa during the 2nd millennium AD.

15

\section{Socio-Political Organization and the Zimbabwe Culture Settlement Pattern}

In a series of papers and two major monographs since the seminal paper in 1981, Huffman has argued that the Zimbabwe Culture spatial pattern developed and was maintained almost unchanged over the several centuries of its lifespan, and was informed and dictated by a system of cultural codes and rules (Huffman, 1984a; Huffman et al., 1986; Huffman, 1996; 2007). In summary, it has been argued that the major sites of the Zimbabwe Culture, such as Mapungubwe, Great Zimbabwe, Khami, Danangombe (Dhlohlo), Zvongombe and Tsindi conformed to a spatial and symbol laden pattern that signified and was guided by the socio-economic and political relations between people within the culture. Based on structuralist theory, it was argued that in the same way society consisted of a series of dichotomies (inside/outside, rich/poor, elite/ commoner, male/female, high/low, old/young) so was the organization of 
space. Among other such dichotomies and symbolic spatial representations and signifiers of different status was the walls themselves which divided elite and commoner people based on the inside/outside principle. By the same logic, Great Zimbabwe and similar ancient towns were argued to reflect a high/ low, ruler/ruled, elite/commoner and male/female dichotomy physically represented by the location of rulers on hilltops and all others on the lower landscape overlooked by the ruler's hilltop residence.

This pattern was argued to represent the symbolic manifestation of political and social status which is thought to have remained an important part of the people's "town planning" and cultural geography through space and time.

The presentation and subsequent elaboration of the structuralist and cognitive theory-based Zimbabwe Culture Settlement Pattern model has been one of the most debated topics in southern African archaeology in the past three decades or so (Beach, 1998; Beach et al., 2013; Chirikure et al., 2014). One of the major critiques has been that the interpretive model adopted a static view of culture and failed to take cultural dynamism and other issues into account (Pwiti, 1996). In this paper, we use two theoretical constructs of recent years to further question and place this debate in context. Using assemblage theory from its various perspectives, we here argue that it is perhaps more useful and more rewarding to view the Zimbabwe Culture settlements as assemblages at two levels (Jervis, 2016; Kertai, 2019; Hamilakis and Jones, 2017). At the wider regional level we see the architectural remains as cultural assemblages that were produced through space and time and as dynamic rather than a constant. We further see them as representing cultural expressions that need to be viewed as a changing assemblage in form and composition. In this regard, we note for example that the original Whitty stylistic classification of the walling styles into P, Q and R with the generally accepted chronological significance and association with the development of different complex state systems of the Zimbabwe Culture is problematic (Shenjere-Nyabezi et al., 2020; Kertai, 2019). Based on detailed architectural observations in north-western Zimbabwe and elsewhere, we have noted that in terms of wall styles, the different styles, previously seen as signifiers of architectural evolutionary development do in fact occur within the same walls at some sites and also occur in combination within and between sites. To this extent, the architecture was not a constant. Similarly, within and between the different socio-political systems, the architecture was a changing cultural phenomenon. This is to the extent that while it is acknowledged that cognitive cultural maps did and do exist, such maps and their production as artifacts would have been subject to and the result of various factors. As such, while the organization of space is culturally meaningful, understanding of it need not be situated within static spatial models. 
Rather, the assemblages that represent the cultural meanings of space would have been constantly shifting and changing. At the site level, the construction of cultural space and the production of an assemblage at this level would also have been subject to change as a result of various factors, geographical, environmental, social, political and economic. This is in the sense that the architectural assemblages that characterize and constitute the Zimbabwe Culture should be regarded not only as architectural arrangements, but things that highlight the processes of arranging (Kertai, 2019). In this sense, the assemblages then become products of various processes operating among people working individually and collectively. As such, in the context of agency theory, we would argue that the production of the stone walls and the wall styles they exhibit, and how the walls define and divide space would have been the outcome of many different and perhaps even conflicting processes that bring in agency as a part of the overall production processes. In terms of the complex spatial arrangements of the Zimbabwe Culture urban configurations therefore, we see them as assemblages that did carry, contain and signify cultural messages but in a changing world rather than conforming to a pre-conceived cultural geography and town plan.

As noted in the introduction, the traditional model for the development of the Zimbabwe Culture complex state systems was influenced by Eurocentric frameworks where state systems rose, declined and collapsed with the collapse of one leading to the rise of another in linear successive fashion. This framework assumed a causative relationship between the decline of one state and the rise of another and correspondingly, the development and collapse and abandonment of their associated capitals. Thus, according to this historical analytical trajectory, the Mapungubwe state developed with its capital at the stone built hilltop site of Mapungubwe in the Shashi-Limpopo basin. The rise of the system during the 11th Century AD was attributed to the accumulation of wealth from external trade based on the export of ivory to the Oriental world via the Indian Ocean coast. It was then argued that when ivory lost its value on the trade market sometime during the 12th Century $\mathrm{AD}$, to be replaced by gold, economic and political power then shifted to Great Zimbabwe, leading to the development of the Zimbabwe state. Great Zimbabwe then developed to become the largest stone built complex in southern Africa between the 13th and the middle of the 15th Century AD. Its size and extent of the monumentality reflected the success of the engagement of the state in the production of 
gold and its export, in exchange for exotic goods such as glass beads, ceramics and cloth. The Zimbabwe state itself was argued to have collapsed during the middle of the 15th Century AD as a result of the loss of the gold trade to the Mutapa state in northern Zimbabwe and the Torwa state based at Khami, the second largest of the Zimbabwe Culture urban capitals. The Torwa and the Mutapa states both came into being as successors to and therefore in a sense off springs of the Zimbabwe state following its collapse. By the same token, the Nambya state based in north-western Zimbabwe with its stone built capitals at the sites of Shangano, Bumbusi and Matoa were also seen as off shoots of Great Zimbabwe. In all cases, it was previously thought that the architecture of the assemblages of the stone built capitals reflected successive and progressive development from Great Zimbabwe. Recent research at the site of Mapela in the Shashi Limpopo Valley, previously thought to have been an offshoot or provincial centre of the Mapungubwe state has shown that it was in fact earlier and overlapped with Mapungubwe and is now thought to have represented a state system that developed at the same time as Mapungubwe (Chirikure et al., 2014). Using such empirical evidence as well as new theoretical frameworks, Chirikure and his associates have demonstrated that views of Mapungubwe having been the place of origin of the Zimbabwe Culture and southern Africa's earliest city and the centre of the region's earliest state system can no longer be acceptable. It is now thought that the stone building culture and its associated political developments may in fact have had multiple centres of origin rather than one centre, a way of thinking which is reminiscent of the abandonment of the arguments for a primary centre for the origins of agriculture and the search for the earliest maize cob! Further problems with the Zimbabwe state and Great Zimbabwe offshoot model have surfaced in north-western Zimbabwe for the origins and development of the Zimbabwe Culture Nambya state. Here, new dating evidence now shows that the state was contemporary with Great Zimbabwe and Khami, rather than an offshoot from one of them as previously thought (Ncube, 2004). Dating evidence recently obtained from one of the capital sites, Shangano, has placed the site occupation and the construction of the stone buildings from as early as the 14th Century AD (ShenjereNyabezi et al., 2020) (Table 4.2).

Elsewhere, for the Mutapa state based in northern Zimbabwe, Pwiti also showed a similar picture where rather than being a direct political successor to the Zimbabwe state as previously and popularly believed, the Mutapa state developed well before the Zimbabwe state had collapsed (Pwiti, 1996). When all this is combined and considered within the context of other new chronological data (see Chirukure et al., (2017) and Table 4.2), the picture that is now emerging is one of very complex multiple faceted socio-political developments 


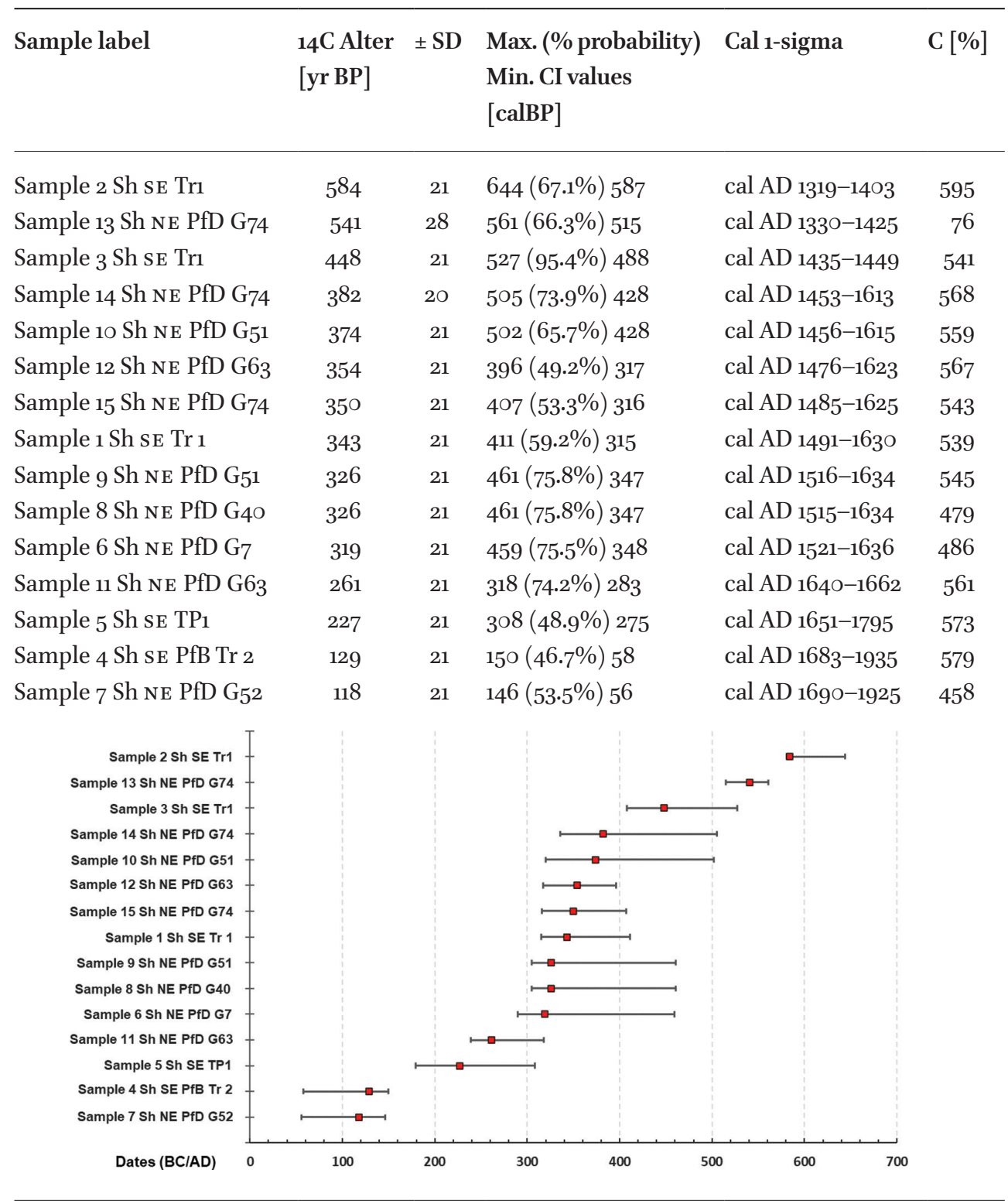

in southern Africa whose understanding must be considered as equally complex (Chirikure et al., 2018). In particular, the production and development of the architectural monumental urban assemblages as centres of political and economic power can no longer be viewed in linear evolutionary terms, using 
rigid spatial models. Rather, as assemblages at the regional and local level, they were subject to processes of change and adaptation to a variety of circumstances (Chirikure et al., 2016).

\section{Conclusions}

The Zimbabwe Culture dominated the social, economic and political landscape of southern Africa for at least six centuries from the 11th Century AD onwards, during which time the region witnessed the origins, growth and prosperity of major political entities commonly referred to as states. Supported by successful economies based on indigenous branches of production and the proceeds from participation in global trading networks, these polities were able to use their wealth, power and social systems to transform many different parts of the regional landscapes into built environments using local resources to develop large stone built population centres that flourished as multi-scale settlements that exhibited many of the attributes of urban assemblages, however defined. While these monumental stone buildings that made up the urban centres have been examined from various perspectives in the past, in this paper, we have employed theoretical constructs such as Costly Signalling Theory and Assemblage Theory to think on why they were erected and how the processes involved in their construction, production and spatial organization are likely to have been the results of a complex combination of factors. In the final analysis, we argue that the Zimbabwe Culture stone buildings reflect engagement in costly signalling and conspicuous consumption in as far as the monumental architectural edifices did not meet any defensive of other functional needs. Engagement in such heavy investment on the part of those who directly participated in the construction activities but did not directly or immediately benefit from the final products might have been motivated by, and situated within the framework of a sense of being part of, belonging and identifying with the power and success of those for whom the buildings were being constructed. Using Assemblage and Agency Theory, we further argue that the buildings themselves, and their spatial and other arrangements as urban centres, were not products of or the result of fixed or standard cultural town planning. Rather, they are best seen as assemblages whose composition, form, meanings and significance are likely to have been subject to change as the centres grew or even shrunk and as new structures were built or added to existing ones. In the end, following the results of new research at the regional level and at the local scale in north-western Zimbabwe, we suggest that the past straight jacketed Western derived interpretations of the political history 
of the Zimbabwe Culture state systems and their capitals as being characterized by successive rises and falls following cause and effect models are no longer supportable, including previous perceptions of the different centres of the state systems as exhibiting progressive refinement in their architectural styles (Chirikure et al., 2016; Shenjere-Nyabezi et al., 2020).

\section{Acknowledgements}

Authors are most thankful for the VolkswagenStiftung Senior Postdoctoral Fellowship Grant under the 'Knowledge for Tomorrow - Cooperative Research Projects in Sub-Saharan Africa Initiative' that provided financial support for the larger project from which this paper grew. Authors appreciate the platform and generous funding provided by the Evolutionary Biology Centre, Uppsala University for the presentation at their Africa, the cradle of human diversity conference and subsequent publication of this work. Authors would like to acknowledge Mukundindishe Chifamba and Elton Sagiya for their assistance and contribution during the many field trips.

\section{References}

Ashkenazi, H. 2020. Sometimes defence is just an excuse: fortification walls of the Southern Levantine Early Bronze Age. Cambridge Archaeological Journal 30(1): 45-67.

Badenhorst, S. 2011. Measuring change: Cattle and caprines from Iron Age farming communities in southern Africa. South African Archaeological Bulletin 66(194): 167-172.

Beach, D. 1998. Cognitive archaeology and imaginary history at Great Zimbabwe. Current Anthropology 39(1): 47-72. https://doi.org/10.1086/204698.

Beach, D., Bourdillon, M. F. C., Denbow, J., Hall, M., Lane, P., Pikirayi, I., and Pwiti, G. 1997. Review feature: Snakes and crocodiles: power and symbolism in ancient Zimbabwe, by Thomas Huffman. South African Archaeological Bulletin 52(166): 125-143.

Bent, J.T. 1896. The ruined cities of Mashonaland: being a record of excavation and exploration in 1891. Longmans, Green, and Co: London, UK.

Bourdillon, M.F.C. 1987. The Shona peoples: an ethnography of the contemporary Shona, with special reference to their religion. Gweru: Mambo Press.

Carneiro, R.L. 1981. The chiefdom: precursor of the state. In: Jones, G.D. and Kautz, R (eds) The Transition to Statehood in the New World, pp. 37-79. 
Chirikure, S., Bandama, F., House, M., Moffett, A.J., Mukwende, T., and Pollard, M. 2016. Decisive evidence for multidirectional evolution of sociopolitical complexity in Southern Africa. African Archaeological Review 33(1): 75-95. https://doi.org/10.1007/ s10437-016-9215-1.

Chirikure, S., Manyanga., Pikirayi., and Pollard, M. 2013. New pathways of sociopolitical complexity in Southern Africa. African Archaeological Review 30(4): 339-366. https://doi.org/10.1007/s10437-013-9142-3.

Chirikure, S., Manyanga, M., Pollard, M., Bandama, F., Mahachi, G., and Pikirayi, I. 2014. Zimbabwe culture before Mapungubwe: new evidence from Mapela Hill, southwestern Zimbabwe. PloS One 9(10). https://doi.org/10.1371/journal.pone.0111224.

Chirikure, S., Mukwende, T., Moffett, A.J., Nyamushosho, R.T., Bandama, F., and House, M. 2018. No big brother here: heterarchy, Shona political succession and the relationship between Great Zimbabwe and Khami, Southern Africa. Cambridge Archaeological Journal. https://doi.org/10.1017/so959774317000555.

Chirikure, S., Nyamushosho, R.T., Bandama, F., and Dandara, C. 2018. Elites and commoners at Great Zimbabwe: archaeological and ethnographic insights on social power. Antiquity 92(364): 1056-1075. https://doi.org/10.15184/aqy.2018.137.

Chirikure, S., Moultrie, T., Bandama, T., and Dandara, C. 2017. What was the population of Great Zimbabwe (CE10oo-18oo)?" PloS One 12(6): eo178335.

Cobbing, J. 1976. The Ndebele under the Khumalos. Unpublished PhD Thesis. University of Lancaster.

Cooper, F., and Brubaker, R. 2005. Identity. In Cooper, F (ed). Colonialism in question: theory, knowledge, and history. University of California Press: Berkeley, USA.

Connah, G. 2015. African civilizations: an archaeological perspective. Cambridge: Cambridge University Press.

Conolly, J. 2017. Costly signalling in archaeology: origins, relevance, challenges and prospects. World Archaeology 49(4): 435-445. https://doi.org/10.108o/oo438243.20 17.140186 o.

Cowgill, G.L. 2004. Origins and development of urbanism: archaeological perspectives. Annual Review of Anthropology, 33(9): 525-549.

Dube, B. 199o. Granite quarrying at Great Zimbabwe. Unpublished paper presented at the "Urban Origins in Eastern and Southern Africa Project Workshop." Harare and Great Zimbabwe.

Fox, C. 1943. The personality of Britain. National Museum of Wales: Cardiff, UK.

Friedman, J., and M. J. Rowlands. 1978. The evolution of social systems: proceedings of a meeting of the "Research Seminar in Archaeology and Related Subjects," Held at the Institute of Archaeology, London University. University of Pittsburgh Press: Pennsylvania, USA.

Garbett, K. 1966. Religious aspects of political succession among the Valley Korekore (N. Shona). Stokes, E. et D. Brown (dir. Puba.), The Zambezian Past. Manchester University Press (MUP): Manchester, UK. 
Garlake, P.S. 1982. Great Zimbabwe Described and Explained. Zimbabwe Publishing House: Harare, Zimbabwe.

Garlake, P.S. 1970. Rhodesian ruins: a preliminary assessment of their styles and chronology. The Journal of African History. https://doi.org/10.1017/soo21853700010422.

Garlake, P.S. 1978. Pastoralism and Zimbabwe. Journal of African History 19(4): 479-93. https://doi.org/10.2307/18116o.

Garlake, P.S. 1983. Prehistory and ideology in Zimbabwe. In: Peel, J. D. \& Ranger, T. O. (eds). Past and Present in Zimbabwe. Manchester University Press: Manchester, UK, pp. 1-19.

Garlake, P.S. 1973. Great Zimbabwe. Oxford Art Online: Oxford, UK. https://doi. org/10.1093/gao/9781884446o54.article.to34177.

Hall, M.J. 1984. The myth of the Zulu homestead: archaeology and ethnography. Africa 54: 65-79. https://doi.org/10.2307/1160144.

Hall, M.J. 1987. The changing past: farmers, kings and traders in Southern Africa, 200186o. D. Philip: Seattle, USA.

Hall, R.N. 1905. The Great Zimbabwe.Journal of the Royal African Society 4(15): 295-300.

Hall, R.N., and Neal., W.G. 1902. The ancient ruins of Rhodesia (Monomotapa Imperium), Methuen \& Company: North Yorkshire, UK.

Hamilakis, Y. and Jones, A.M. 2017. Archaeology and assemblage. Cambridge Archaeological Journal. https://doi.org/10.1017/so9597743160oo688.

Harris, M. 1977. Cannibals and Kings: The origins of culture. William Collins \& Sons: Glasgow, UK.

Hodder, I. 1982a. Symbols in action. Ethnoarchaeological studies of material culture. Cambridge University Press: Cambridge, UK.

Hodder, I. 1982b. The Present Past. An introduction to anthropology for archaeologists. Pen and Sword: Barnsley, UK.

Hodder I. and Orton, C. 1976. Spatial analysis in archaeology. Cambridge University Press: Cambridge, UK.

Hodder, I. and Hutson, S. 2003. Reading the past. Current approaches to interpretation in archaeology. Cambridge University Press: Cambridge, UK.

Hodder, I., Renfrew, C. and Gamble, C. 1982. Symbols in action: ethnoarchaeological studies of material culture. Cambridge University Press: Cambridge, UK.

Huffman, T.N. 1981. Snakes and birds: expressive space at Great Zimbabwe. African Studies 4O(2): 131-5o. https://doi.org/10.1080/00020188108707574.

Huffman, T.N. 1984a. Expressive space in Zimbabwe Culture. Man 19(4): 593-612.

Huffman, T.N. 1984b. Leopard's Kopje and the nature of the Iron Age in Bantu Africa. Zimbabwea 1(1): 28-35.

Huffman, T.N. 1986a. Iron Age settlement patterns and the origins of class distinction in southern Africa. In: Wendorf, F., and Close, E. (eds) Advances in World Archaeology 5, pp. $291-338$. 
Huffman, T.N. 1986b. Archaeological evidence and conventional explanations of Southern Bantu settlement patterns. Africa 56(3): 28o-298.

Huffman, T.N. 1996. Snakes and crocodiles: power and symbolism in ancient Zimbabwe. Johannesburg: Witwatersrand UP.

Huffman, T.N. 1993. Broederstroom and the Central Cattle Pattern. South African Journal of Science 89: 220-226.

Huffman, T. N. 2001. The Central Cattle Pattern and interpreting the past. Southern Africa Humanities 13: 19-35.

Huffman, T.N. 2007. A handbook to the Iron Age: the archaeology of precolonial farming societies in southern Africa. Pietermaritzburg: University of KwaZulu-Natal Press: KwaZulu-Natal, South Africa.

Huffman, T.N., Ashton, E.H., Blacking, J., Burchell, W.J., Ellenberger, V., and Goodwin, A.J.H. 1986. Archaeological evidence and conventional explanations of southern Bantu settlement patterns. Africa, Quaderni 56(o3): 28o-98. https://doi.org/10.2307/ 1160685 .

Jervis, B. 2016. Assemblage theory and town foundation in Medieval England. Cambridge Archaeological Journal 26(3): 381-395. https://doi.org/10.1017/so959774316000159.

Kapumha, R. 2019. The cultural identity and spatial organization of stone structures in eastern Zimbabwe: A case study of later farming communities in Chipinge and Chimanimani Unpublished PhD Thesis. History Department (Archaeology Unit), University of Zimbabwe: Harare, Zimbabwe.

Kertai, D. 2019. Architectural assemblages: the northwest complex atZincirli. Cambridge Archaeological Journal 29(1): 81-101 https://doi.org/10.1017/so95977431800o379.

Kim, N.C., Kusimba, C.M., and Keeley, L.H. 2015. Coercion and warfare in the rise of state societies in Southern Zambezia. African Archaeological Review 32(1): 1-34. https://doi.org/10.1007/s10437-015-9183-x.

Kuper, A. 1982. Wives for cattle: bridewealth and marriage in Southern Africa. Routledge and Kegan Paul Books: London, UK.

Kuper, A. 1980. Symbolic dimensions of the Southern Bantu homestead. Africa:Journal of the International Institute of African Languages and Cultures 5O(1): 8-23.

Kusimba, C.M., Kim, N.C., and Kusimba, S.B. 2017. Trade and state formation in ancient East African Coast and Southern Zambezia. In: Chacon, R.J. and Mendoza R.G. (eds) Feast, Famine or Fighting? Multiple Pathways to Social Complexity, 61-89. Cham: Springer International Publishing. https://doi.org/10.1007/978-3319-48402-O_4.

Lane, P. 1994. The use and abuse of ethnography in the study of the Southern African Iron Age. Azania: Archaeological Research in Africa 29: 51-64. https://doi. org/10.1080/oo672709409511661.

Maggs, T. 1984. The Iron Age south of the Zambezi. In: Klein R.G. (ed) Southern African Prehistory and Palaeoenvironments. CRC Press: Florida, USA, pp. 329-36o. 
Maggs, T. 1992. Name calling in the Iron Age. The South African Archaeological Bulletin 47(156): 131.

Mahachi, G., and Ndoro, W. 1997. The socio-political context of Southern African Iron Age Studies with special reference to Great Zimbabwe. In: Pwiti, G. (ed) Caves, Monuments and Texts: Zimbabwean archaeology today (Studies in African Archaeology 14). Department of Archaeology and Ancient History: Uppsala, Sweden, pp. 89-104.

Matenga, E. 1996. Conservation history of the Great Enclosure, Great Zimbabwe, with reference to the proposed restoration of a lintel entrance. In Pwiti, G. \& Soper, R. (eds) Aspects of African Archaeology. University of Zimbabwe Publications: Harare, Zimbabwe.

McIntosh, S.K., and McIntosh, R.J. 1984. The early city in West Africa: towards an understanding. The African Archaeological Review 2(1): 73-98. https://doi.org/10.1007/ bfol117226.

McIntosh, S.K. 1999. Beyond chiefdoms: pathways to complexity in Africa. Cambridge University Press: Cambridge, UK. https://doi.org/10.2307/220371.

Mtetwa, Ezekia. 2017. Technology, ideology and environment: the social dynamics of iron metallurgy in Great Zimbabwe, AD goo to the present. Published PhD Thesis. Department of Archaeology and Ancient History: Uppsala, Sweden.

Mudenge, S.I.G. 1974. The role of foreign trade in the Rozvi Empire: a reappraisal. Journal of African History 15(3): 373-91. http://www.jstor.org/stable/180666.

Mudenge, S.I.G. 1988. A political history of Munhumutapa c 1400-1902. James Currey Publisher: Somerset, UK.

Mujere, J. 2019. Land, Migration \& Belonging. A History of the Basotho in Southern Rhodesia c. 1890-196os. James Currey Publisher: Somerset, UK. https://doi. org/10.1017/9781787444157.

Mukwende, T. 2018. An archaeological study of the Zimbabwe Culture capital of Khami, southwestern Zimbabwe. Unpublished PhD Thesis. University of Cape Town: Cape Town, South Africa.

Ncube, G.T. 2004. A history of Northwestern Zimbabwe, 1850-1960. Kadoma: Mond Books. https://play.google.com/store/books/details?id=n8ByAAAAMAAJ.

Ndoro, W. 2001. Your monument our shrine: the preservation of Great Zimbabwe. Vol. 19. Published PhD Thesis. Department of Archaeology and Ancient History, Uppsala University: Uppsala, Sweden.

Nyamutswa, C. 2017. Great Zimbabwe: Who Built It and Why? Harare: Themba Books.

O'Driscoll, J. 2017. Hillforts in prehistoric Ireland: a ccostly display of power? World Archaeology 49(4): 506-525. https://doi.org/10.108o/oo438243.2017.1282379.

Phillipson, D.W. 1977. The later prehistory of Eastern and Southern Africa. Heinemann Educational Publishers: Portsmouth, USA.

Pikirayi, I. 2001. The Zimbabwe Culture: origins and decline of Southern Zambezian States. Walnut Creek: Altamira Press: Lanham, USA. 
Pikirayi, I. 2013. Stone architecture and the development of power in the Zimbabwe Tradition AD 1270-1830. Azania: Archaeological Research in Africa 48(2): 282-300. https://doi.org/10.1080/0067270X.2013.789225.

Pwiti, G. 1996a. Continuity and change: an archaeological study of farming communities in northern Zimbabwe. Published PhD Thesis. Uppsala University: Uppsala, Sweden.

Pwiti, G. 1996b. Let the ancestors rest in peace? New challenges for cultural heritage management in Zimbabwe. Conservation and Management of Archaeological Sites 1(3): 151-6o. https://doi.org/10.1179/135050396793136982.

Pwiti, G. 1996c. Peasants, Chiefs and kings: a model of the development of cultural complexity in northern Zimbabwe. Zambezia 23(1): 31-52. https://journals.co.za/ doi/abs/10.10520/AJAo3790622_196.

Pwiti, G. 1996d. Review of Snakes and crocodiles: Power and symbolism in Ancient Zimbabwe. Johannesburg: Witwatersrand University Press, by Thomas Huffman. 1996. Antiquity (273) \& South African Archaeological Bulletin 52, 166.

Pwiti, G. 2004. Economic change, ideology and the development of cultural complexity in northern Zimbabwe. Azania: Archaeological Research in Africa 39(1): 265-82. https://doi.org/10.1080/00672700409480403.

Pwiti, G. 2005. Southern Africa and the east African coast. In: Stahl, A.B. (ed) African Archaeology: A critical introduction, Blackwell Publishing: Oxford, UK, pp. 378-391.

Renfrew, C. 1984. Approach to social archaeology. Edinburgh University Press: Edinburgh, UK. http://www.openbibart.fr/item/display/10o68/1233426.

Robinson, K.R. 1959. Khami ruins: report on excavations undertaken for the Commission for the Preservation of Natural and Historical Monuments and Relics, Southern Rhodesia. Cambridge University Press: Cambridge, UK.

Scholfield, J.R. 2019. Exploring networks of interaction at the Iron Age Site of Mtanye, South Western Zimbabwe. Faculty of Science: Harare, Zimbabwe. https://open.uct. ac.za/handle/11427/31815.

Shenjere-Nyabezi, P. 2016. Imperceptible realities: an ethnoarchaeological perspective on the acquisition, ownership and management of cattle by women in Southeastern Zimbabwe. Azania: Archaeological Research in Africa 51(3):380-402. https://doi. org/10.1080/oo67270X.2016.1220054.

Shenjere-Nyabezi, P. 2018. Pastoralism and socio-political structure in precolonial Zimbabwe. In: Überschuss Ohne Staat-Politische Formen in Der Vorgeschichte: 10. Mitteldeutscher Archäologentag Vom 19. Bis 21. Oktober 2017 in Halle (Saale), 407-29. Landesmuseum für Vorgeschichte. https://dialnet.unirioja.es/servlet/ articulo? codigo $=6639919$.

Shenjere-Nyabezi, P., Pwiti, C., Sagiya, E., Chirikure, S., Ndoro, W., Kapumha, R., and Makuwaza, S. 202O. Style, chronology and culture: a critical review of Whitty's stylistic classification of Zimbabwe Culture using evidence from the Hwange District, northwestern Zimbabwe. South African Archaeological Bulletin, 75(212): 1-13. 
Sinclair, P.J.J. 1987. Space, time and social formation: a territorial approach to the archaeology and anthropology of Zimbabwe and Mozambique c o-1700 AD. Published PhD Thesis. Uppsala: Societas Archaeologica Upsaliensis: Uppsala, Sweden.

Sinclair, P.J.J., Pikirayi, I., Pwiti, G., and Soper, R. 1993. Urban trajectories on the Zimbabwean Plateau. In: Shaw, T., Sinclair, P., Andah, B., and Okpoko, A. (eds), The Archaeology of Africa: food, metals and towns. Routledge: London, UK, pp. 705-732.

Wenke, R.J. 1989. Egypt: origins of complex societies. Annual Review of Anthropology 18(1): 129-155. https://doi.org/10.1146/annurev.an.18.100189.0o1021.

Whitty, A. 1959. A classification of prehistoric stone buildings in Mashonaland, Southern Rhodesia. The South African Archaeological Bulletin 14(54): 57-71. https:// doi.org/10.2307/3886639.

Whitty, A. 1961. Architectural style at Zimbabwe. Occasional Papers of the National Museums of Southern Rhodesia 3(23A): 289-305.

Wright, J. 2017. The honest labour of stone mounds: monuments of Bronze and Iron Age Mongolia as costly signals. World Archaeology 49(4): 547-576. 